\title{
The Impact of Firm Financial Efficiency on Executive Compensation of United States Apparel Stores Industry: An Application of Panel Data Envelopment Analysis
}

\author{
Herman Sahni ${ }^{1} \&$ Christian Nsiah ${ }^{1}$ \\ ${ }^{1}$ School of Business, Baldwin Wallace University, Berea, Ohio, United States of America \\ Correspondence: Herman Sahni, School of Business, Baldwin Wallace University, Berea, OH 44017, United \\ States of America.
}

Received: April 20, 2018

doi:10.5539/ibr.v11n6p165

\author{
Accepted: May 11, $2018 \quad$ Online Published: May 18, 2018 \\ URL: https://doi.org/10.5539/ibr.v11n6p165
}

\begin{abstract}
This study examines the effect of firm financial efficiency on executive compensation with an emphasis on the US apparel industry. We find that both annual efficiency levels and cumulative efficiency changes obtained from the Data Envelopment Analysis (DEA) are positively associated with CEO pay. The effect is stronger for technological changes and changes in scale efficiency. Our results seem to support the pay-for-efficiency paradigm, a stricter version of the pay-for-performance framework under the efficient contracting explanation for CEO pay.
\end{abstract}

Keywords: apparel industry, data envelopment analysis, efficient contracting, executive compensation, financial efficiency, Malmquist productivity index

\section{Introduction}

CEO compensation has been a hot topic of discussion for decades. From 1978 to 2014, the inflation-adjusted average CEO compensation in the USA increased by $997 \%$ compared to about $11 \%$ for a typical worker (Mishel \& Davis, 2015). The CEO-to-worker compensation ratio shows an even worse scenario - from 20.2 in 1965 to 279.5 in 2016 (Mishel \& Scheider, 2017). A nationwide survey of 1,202 people by the Rock Center of Stanford University revealed that CEO compensation is not accurately set relative to the average worker in the firm. As indicated in Figure 1 below, average executive pay has been on an upward trajectory except a few years.

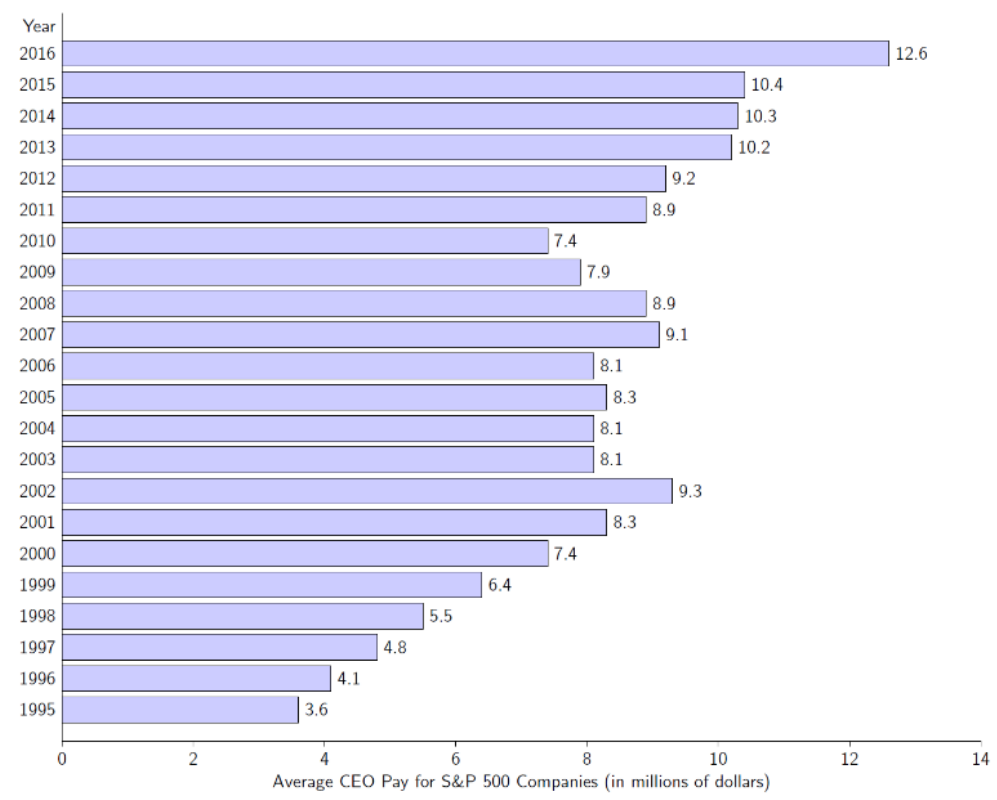

Figure 1. Average CEO Pay (in \$ millions) for S\&P 500 Companies (Equilar, 2016) 
Many CEOs saw their pay go up even as their companies performed poorly (Jensen \& Murphy, 2010). This disconnect between CEO pay and firm performance brought to the forefront once again the question of why CEOs are exorbitantly paid for the performance they produce. In this paper, we attempt to put forward another measure, the firm's financial efficiency, as an explanation for executive compensation levels.

Our sample is made up of 21 publicly traded apparel companies in the United States. The average CEO pay for this sample of firms in 2015 was USD 7.3 million. In comparison, the average CEO pay of S\&P 500 companies during the same year was USD 10.4 million. The top five earners in this industry for the year 2015 are Leslie $\mathrm{H}$. Wexner of L Brands (USD 27.2 million), Carol M. Meyrowitz of TJX (USD 19.6 million), Julian R. Geiger of ARO Liquidation (USD 10.8 million), Barbara Rentler of Ross Stores (USD 10.2 million), and Jane T. Elfers of Children's Place (USD 9.8 million).

The objectives of this study are twofold. First, we estimate the annual levels and the cumulative changes in efficiency for apparel stores via dynamic data envelopment analysis (DEA). Second, we examine the relationship between these efficiency measures and CEO compensation. Previous research which sought to investigate the determinants of CEO compensation use firm performance measures such as return on assets and stock returns in isolation. In contrast, our study combines a wide variety of financial performance indicators into one measure financial efficiency, making our analysis richer. This is our main contribution, and to the best of our knowledge, this is the first study to apply firm financial efficiency measurements to executive compensation analysis.

The rest of this paper is organized as follows: Section 2 presents a summary of the previous related literature, section 3 discuss the data and empirical models employed by this study, section 4 discusses the empirical results, and section 5 concludes.

\section{Literature Review}

There are two related but distinct strands of literature that we must consider due to the nature of our study - (1) firm performance measurement, and (2) CEO compensation.

It is a well-known fact that executive compensation has been under scrutiny for several decades, with several critics arguing that top corporate executives are overcompensated. However, corporations tend to defend their executive compensation using two rationales. On the one hand, there is the efficient contracting framework which argues that firms offer lucrative pay packages for CEOs to attract talented candidates and to extract optimal effort. Here, one should expect that firms with high-paid CEOs also yield high financial performance. On the other hand, some argue that CEO pay serves as a reward for previous work done, indicating that there should be a positive relationship between current CEO pay levels and past firm performance.

Several other studies (e.g. Eisenhardt, 1989; Baiman, 1990; Gerhart \& Milkovich, 1992) argue that one of the possible solutions to solving the agency issue is to find ways to induce the self-seeking agent to act in the best interest of the principals they represent. As succinctly put by Tosi, Werner, Katz, and Gomez-Mejia (2000), there are two main ways of doing so. First, the agents could establish a system of monitoring the managers to ensure their decision making do not deviate from the stockholders' best interest, which is difficult to do for such dispersed stockholders in the presence of board members who may themselves be optimizing their own wellbeing. The second proposed solution to the agency issue is to establish an incentive system that aligns the agent's incentives to the company performance (Fama, 1980).

The studies on CEO compensation and firm performance have not achieved a consensus on the direction and the magnitude of the impact of firm performance on CEO compensation. In firm performance literature, many different profitability proxies including return on equity (ROE), return on assets (ROA), stock market capitalization, annual stockholder's return amongst other financial profitability ratios have been employed, sometimes yielding different findings. In their 2003 study, Engel, Hayes, and Wang contend that accounting performance proxies such as profit, ROA, and ROE, as well as market-based performance yardsticks such as stock price and total shareholder returns, are the primary basis of executive termination decisions. In this spirit, the rest of our literature review will focus on these performance variables.

\subsection{Market-Based Performance}

Regarding market-based performance, several different proxies have been used by earlier studies with varying results. The earlier work of Jensen and Murphy (1990) analyzed the pay-for-performance theory using shareholder wealth as a proxy for performance. Even though they found a positive relationship, they failed to find a very strong empirical relationship between CEO compensation and stockholders wealth, thus, calling into question the pay-for-performance theory. Jouber and Fakhfakh (2011) in their study of 300 publicly traded firms found that a positive impact of performance measured by total shareholder return for the year, however, they 
concluded that the CEO pay to performance elasticity is positively correlated to the strength of shareholder rights.

Contrarily, many other studies have found a significant positive relationship between a firm's stock performance and CEO compensation. Hill and Phan in their 1991 study analyzed the relationship between CEO pay and stock return for the 1977-1988 period, finding a positive correlation between CEO pay and stock return. However, they also found that this relationship weakens with CEO tenure. Using stock returns as a proxy for performance, Shaw and Zhang (2010) indicated that changes in CEO cash-based pay were significantly positively related with stock returns, which they argue that CEOs of better performing firms were better rewarded. Similarly, in a study of 16 US firms, Boschen and Smith (1995) found that albeit being permanent, past stock return significantly impacts current executive compensation. In a 2016 Wall Street Journal article, Francis reported the NSCI's corporate governance study that investigates the CEO compensation among the 400 large and mid-sized US firms between 2006 and 2015. They found an inverse relationship between stock price performance and CEO compensation. In their 2006 study, Leone, Wu, and Zimmerman found that the relationship between stock market return and CEO compensation may be non-linear. Specifically, they found that CEO pay is more sensitive to adverse stock returns than to positive stock returns. They also found that compensation elasticity for negative returns is twice that of positive returns. Similarly, Shaw and Zhang (2010) concluded that CEO cash compensation is not penalized for lackluster stock returns.

\subsection{Accounting Performance Proxies}

Cooper, Gulen, and Rau (2016) argue that the variation in current compensation not explained by current observable performance factors may be highly correlated to future performance. In their opinion, analysts in this camp tend to rely more on accounting-based performance measures such as ROA and ROE. Other studies have analyzed the relationship between ROA, ROE, and CEO compensation with varying results. ROE is positively related to the compensation of executives (Carr, 1997; Berrone \& Gomez-Mejia, 2009; Sigler, 2011; Banker, Darrough, Huang, \& Plehn-Dujowich, 2013; Ismail, Yabai, \& Hahn, 2014). Similarly, ROA is also positively related to executive compensation (Yatim, 2012; Pathak, Hoskisson, \& Johnson, 2014; Ismail et al., 2014; Paul \& Sahni, 2017).

Contrarily, some studies employing ROA and ROE as performance proxies found a significant negative relationship or no relationship at all. Jouber and Fakhfakh (2011) studying 300 international firms find no significant impact of ROE on CEO pay. Interestingly, they even found a negative relationship between CEO compensation and ROA. Abed, Suwaidan, and Slimani (2014) in a study of a sample of 266 publicly traded industrial companies in Jordan for the period 2004-2009 found that whereas factors such as CEO tenure, age, and company size have a significant impact on CEO pay, they found no significant effect of firm performance measured by ROA. Similarly, Finkelstein and Hambrick (1989) in their study of the leisure industry's executive compensation trends found that while ROE is positively related to executive bonuses, it has no impact on the salary of these executives. They hypothesize that the insignificant relationship is because salaries are set ex-ante, indicating that wages are not performance based and as such does not drive performance, hence discounting the efficiency wage argument. In their study of 205 publicly traded US firms drawn from different industries, Core, Holthausen, and Larcker (1999) found that ROA has no significant impact on executive compensation. Using data from 15512 firms from 1993 to 2006, Banker et al. (2013) indicated that ROE and stock performance have a positive and a significant relationship with CEO equity compensation and CEO total pay. Nonetheless, they show a negative correlation between ROE and bonus.

Other studies have used different measures of firm performance (apart from ROA and ROE) such as operating profits to examine the impact of firm performance on CEO pay. For example, Lewellen and Huntsman (1970) found a significantly positive link between CEO compensation and profit measures. Weichenrieder (2009) found that only firms with low concentrations of investor ownership have a small relationship between CEO pay and firm profits. However, those with highly concentrated ownership have no link at all. In a study of 100 firms over a five-year period, Ismail et al. (2014) concluded that there is a weak positive relationship between profit margin and CEO pay. Vemala, Nguyen, Nguyen, and Kommasani (2014) selected annual revenue and net income as proxies for firm performance. The dependent variables include CEO bonus and salary. Using time-series cross-sectional regression to study the relationships within a sample of Fortune 500 firms listed in 2008 with 2241 observations, they found that CEO compensation has a significant positive correlation with firm size and firm performance.

\subsection{Literature Review Conclusions}

From the existing literature, we can conclude that performance can significantly positively impact executive 
compensation. At the same time, these previous studies investigating the link between firm performance and executive compensation narrowly focused on one proxy for firm performance without genuinely looking at the overall efficiency of the firms. Also, none of the previous research has explicitly focused on the compensation for executives in the apparel industry.

In terms of accounting performance measures, one of the most used in the existing literature is ROE, which in turn can be decomposed into profit margin (PM) (measuring operating efficiency), total asset turnover (TAT) (measuring asset use efficiency), and the leverage proxied by equity multiplier (EM), using the DuPont system of equations. That is, ROE can be calculated as PM $\times$ TAT $\times$ EM. From this equation, one can argue that an increase in ROE can directly result from an increase in debt levels. Therefore, it is essential that studies which use ROE as a performance measure need to control for the effects of debt, something most of the previous studies ignore. Further, ROA can be deduced from the first components of the DuPont system $(\mathrm{PM} \times \mathrm{TAT})$. While ROA is an adequate performance measure for most corporate finance studies, it does not encompass the full spirit of a firm's financial efficiency as a performance measure.

In actuality, there are several possible proxies for accounting performance which could be employed. However, the magnitude and the direction of the impact of performance on CEO pay are sensitive to the type of performance proxy being used. Hence, the use of different accounting performance proxies is one source of the inconsistencies in the link between performance and CEO compensation reported by previous literature. Also, most accounting performance proxies measure different aspects of efficiency, which often are correlated with each other, and as such cannot be used in the same regression. On the other hand, eliminating one or more of these proxies from the analysis may lead to omitted variable bias.

In an attempt to circumvent the issues described above, we propose the use of the more comprehensive performance measure estimated in line with data envelopment analysis techniques (DEA) called the Malmquist Productivity Index. This model allows us to account for both inputs and outputs in measuring firm efficiency and the growth of efficiency over time. It also allows us to distinguish different aspects of efficiency. We believe that the DEA type measures of efficiency have significant advantages over individual financial ratios because it circumvents the "one ratio at a time" issue. More importantly, this approach may also provide analysts the ability to break up the changes in total factor productivity into its components (technological change and technical change). Thus, this methodology presents the analyst with the ability to detect the primary determinants of the movements in total factor productivity (Deliktas, 2002).

In their 2004 analysis of the Greek banking sector, Halkos and Salamouris conclude that DEA can be used as either a substitute or a complement to traditional financial ratios in estimating firm performance. Feroz, Kim, and Raab (2003) also document similar findings. Whereas DEA type analysis has been used by some previous studies in analyzing firm performance (e.g. Chandra, Cooper, Li, \& Rahman, 1998; Mahadevan, 2002; Feroz et al., 2003; Eslami-Bidgoli \& Kashani-Poor, 2004; Tehrani, Mehragan, \& Golkani, 2012), to our knowledge no study has applied the efficiency scores obtained from the DEA analysis as a determinant of executive compensation.

We thus contribute to the existing literature by examining the effect of DEA type efficiency scores on executive compensation for the apparel industry. Specifically, we employ the Malmquist Total Factor Productivity Index, which apart from providing us with static efficiency scores, also provides us with the technical change, technological change, pure efficiency change, and scale efficiency change scores.

\section{Research Questions, Contributions, and Empirical Models}

\subsection{Research Questions}

The primary research objective of our study is to examine the relationship between the financial efficiency and the CEO compensation of publicly traded US apparel firms. Specifically, given operational, financial inputs and outputs, our central research question is the following: does firm financial efficiency explain the differences in compensation of the CEOs of US publicly traded apparel firms? This research question can be divided further into three related issues: (1) Does measuring annual efficiency scores using variable (VRS) and constant (CRS) returns to scale assumptions lead to significant differences in how static firm efficiency impacts CEO compensation? (2) Do changes in efficiency impact CEO pay? (3) Do different aspects of efficiency (catch up, technical, pure, and scale efficiencies) have a significant differential impact on CEO pay (Note 1)?

\subsection{Contributions to Existing Literature}

The main contribution of our study is the following: using a dynamic input and output model, we investigate the relationship between firm's overall internal efficiency and executive compensation. To our knowledge, this study 
is the first to describe the link above. Our other contributions are as follows. First, this study estimates the efficiency scores, changes in total factor productivity, and changes in different efficiency component factors for US apparel industry firms. Second, this study documents the relationship between changes in various efficiency component factors and executive compensation. Third, to our knowledge, this study is the first to investigate executive compensation in the US apparel industry.

\subsection{Research Methodology}

By design, our analysis consists of a two-stage process. In stage one we estimate the efficiency levels and cumulative efficiency changes of apparel industry firms. In stage two, we examine the relationship between the efficiency scores estimated in step one (and their cumulative changes) and the CEO compensation.

\subsubsection{Measuring the Efficiency and Productivity of Publicly Traded US Apparel Firms}

Our study seeks to estimate financial efficiency scores and their cumulative changes for US publicly traded apparel companies. The two commonly employed efficiency estimation techniques in the existing literature include parametric and nonparametric frontier estimation techniques. In the view of Jarzebowski (2013), both methodologies have their merits and disadvantages. For our analysis, however, we employ a nonparametric efficiency scores estimation model called the Malmquist Production Index (MPI), popularized by Caves, Christensen, and Diewert (1982). One of the criticisms of this model is that it does not provide a means of estimating inefficiency scores. Fare, Grosskopf, and Norris (1997) solved the problem. It is worth noting that the MPI estimator is dependent on data envelopment analysis (DEA), which itself is a linear programming (LP) based model. The model not only presents the annual efficiency scores similar to the DEA models but also gives the rate of productivity changes between periods for each decision-making unit (in our case, firms).

Before describing the MPI formula specification, it is appropriate to delineate two groups of linear programming distance functions as given in equations 1 and 2 .

$$
\begin{gathered}
\left\{\widehat{\mathrm{D}}_{\mathrm{i}}^{\mathrm{t}}\left(\mathrm{x}_{\mathrm{i}}^{\mathrm{t}}, \mathrm{y}_{\mathrm{i}}^{\mathrm{t}}\right)\right\}^{-1}=\max \theta \\
\text { s.t. } \quad \theta y_{i m \leq \sum_{j=1}^{L} \tau_{j}^{t} y_{m j}^{t} ; m=1, \ldots, M ; \sum_{j=1}^{L} \tau_{j}^{t} x_{j n}^{t} \leq x_{i n}^{t}, n=1, \ldots, N ; \tau_{i}^{t} \geq 0, \mathrm{i}=1, \ldots, \mathrm{L} .}
\end{gathered}
$$

where $\mathrm{x}_{\mathrm{i}}$ and $\mathrm{y}_{\mathrm{i}}$ denote inputs and output for company $\mathrm{i}$, respectively, and $\mathrm{t}$ denotes period one. $\tau_{i}^{t}=$ $\left(\tau_{1}^{t}, \ldots, \tau_{L}^{t}\right)$ is a vector of weights that forms a convex combination of each company's efficiency observation relative to the reference country in the analysis. We can replace $t$ with $t+1$ to reflect the next period information. These calculations measure the distance of each company's efficiency score from the reference best practice company for each year. The inverse of Equation 1 presents DEA type efficiency scores for any period and company. It is worth noting that $\widehat{D}_{i}^{t}=1$ indicates the $\mathrm{i}^{\text {th }}$ company is technically efficient, thus on the efficiency frontier. On the other hand, $\widehat{D}_{i}^{t} \leq 1$ denotes a technically inefficient company. The distance between a company's efficiency score and the frontier value of one (1) represents the magnitude of the technical inefficiency of the company in question for that year.

$$
\begin{gathered}
\left\{\widehat{\mathrm{D}}_{\mathrm{i}}^{\mathrm{t}}\left(\mathrm{x}_{\mathrm{i}}^{\mathrm{t}+1}, \mathrm{y}_{\mathrm{i}}^{\mathrm{t}+1}\right)\right\}^{-1}=\max \theta \\
\text { s.t. } \quad \theta y_{i m \leq \sum_{j=1}^{L} \tau_{j}^{t} y_{m j}^{t} ; m=1, \ldots, M ; \sum_{j=1}^{L} \tau_{j}^{t} x_{j n}^{t} \leq x_{i n}^{t+1}, n=1, \ldots, N ; \tau_{i}^{t} \geq 0, \mathrm{i}=1, \ldots, \mathrm{L} .}
\end{gathered}
$$

Equation 2 includes information for time $t$ and time $t+1$. We can also switch the periods in Equation 2 and calculate a second mixed period distance function denoted by $\widehat{D}_{i}^{t+1}\left(x_{i}^{t}, y_{i}^{t}\right)$. This set of two equations measures the distance of the reference technology in period $t+1$ relative to time t. Historically, the estimation of Equations 1 and 2 has been done with an assumption of either constant returns to scale (CRS) or variable return to scale (VRS) assumptions. While we investigate the static relationship between efficiency and executive compensation considering both CRS and VRS assumptions, for our goal of investigating the deferential relationships between executive compensation and different types of efficiencies and their cumulative growth, we deploy the CRS to aid us with our estimation of the distance functions which we will use for our Malmquist Productivity Index. Further, Grifell-Taje and Lovell (1995) indicate that the Malmquist Index typically underperforms in estimating productivity index when the model specification is not CRS. One can model equations 1 and 2 from the perspective of input minimization or output maximization. For our analysis, we employ input minimization orientation.

The change in the Malmquist Total Factor Productivity Index (MPI) is calculated as the geometric mean of the input-based Malmquist Production Indices for period's $t$ and $t+1$ is presented in Equation 3.

$$
M P I\left(y^{t+1}, x^{t+1}, y^{t}, x^{t}\right)=\left[\frac{D^{t}\left(y^{t+1}, x^{t+1}\right)}{D^{t}\left(y^{t}, x^{t}\right)} \times \frac{D^{t+1}\left(y^{t+1}, x^{t+1}\right)}{D^{t+1}\left(y^{t}, x^{t}\right)}\right]^{1 / 2}
$$


The MPI specifically measures the productivity changes along with time variations. As shown in Figure 2, this index can be decomposed into efficiency change, also known as "catch up effect" (EFFCH) and technical change between the two periods, respectively (TECHCH).

Equation 4 split Equation 3 into two categories described above.

$$
\operatorname{MPI}\left(y^{t+1}, x^{t+1}, y^{t}, x^{t}\right)=\left[\frac{D^{t+1}\left(x^{t+1}, y^{t+1}\right)}{D^{t}\left(x^{t}, y^{t}\right)}\right]\left[\frac{D^{t}\left(y^{t+1}, x^{t+1}\right)}{D^{t+1}\left(y^{t+1}, x^{t+1}\right)} X \frac{D^{t}\left(y^{t}, x^{t}\right)}{D^{t+1}\left(y^{t}, x^{t}\right)}\right]^{1 / 2}
$$

The first part of the equation measures the technical efficiency change and the second argument measures the pure technical change between periods. The pure technical change essentially measures the shift in the reference frontier, whereas the efficiency change measures "catch up" in technical efficiency, i.e. it measures how much closer or further away an apparel firm gets from the firms in the industry with best practice with regards to financial efficiency.

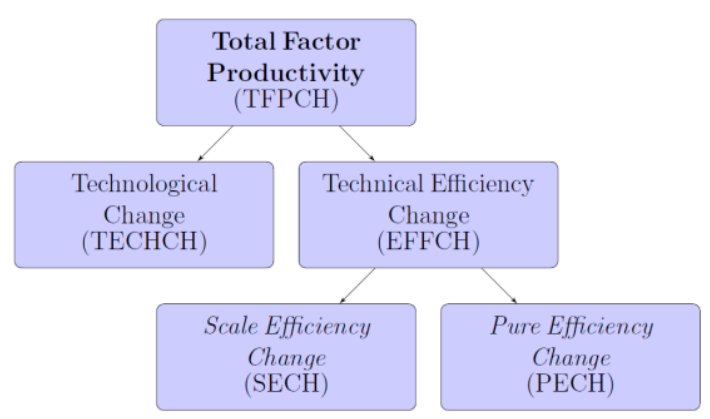

Figure 2. Malmquist Productivity Index Growth Breakdown

As indicated in Figure 2 technical efficiency change can be further subdivided into two parts (Lee, Leem, Lee, \& Lee, 2011) including a scale efficiency change (SECH) and a pure efficiency change (PECH). These measures are represented by equations 5 and 6 , respectively.

$$
\begin{aligned}
& S E C H=\left[\frac{\frac{D_{v r s}^{t+1}\left(x^{t+1}, y^{t+1}\right)}{D_{c r s}^{t+1}\left(x^{t+1}, y^{t+1}\right)}}{\frac{D_{v s}^{t+1}\left(x^{t}, y^{t}\right)}{D_{c r s}^{t+1}\left(x^{t}, y^{t}\right)}} X \frac{\frac{D_{v r s}^{t}\left(x^{t+1}, y^{t+1}\right)}{D_{c r s}^{t}\left(x^{t+1}, y^{t+1}\right)}}{\frac{D_{v r s}^{t}\left(x^{t}, y^{t}\right)}{D_{c r s}^{t}\left(x^{t}, y^{t}\right)}}\right]^{1 / 2} \\
& \text { PECH }=\frac{D_{v r s}^{t+1}\left(x^{t+1}, y^{t+1}\right)}{D_{c r s}^{t}\left(x^{t}, y^{t}\right)}
\end{aligned}
$$

The MPI enables us to compare the productivity change within an industry as well as the productivity changes within each decision-making unit in the industry. Thus, it provides us with the ability to investigate catch up and retrogressions. In interpreting the MPI, all scores higher than one, equal to one, and less than one represents efficiency improvements, no change in efficiency, and deterioration of efficiency, respectively.

\subsection{Data}

The data for this study is from Bloomberg's firm-level data. This study focuses on a balanced panel of 21 publicly traded US apparel stores from 2004 to 2015. Appendix A provides the list of firms. The sample was largely determined by the availability of the data of input and output variables needed for efficiency estimation. The final sample consists of 252 firm-year observations.

\subsubsection{Efficiency Scores Estimation}

For this study, we specifically focus on the efficiency of the financial inputs in the operations of the apparel store industry's internal operational process. Our analysis focuses only on financial efficiency, and as such our input and output variables are all financial variables. 


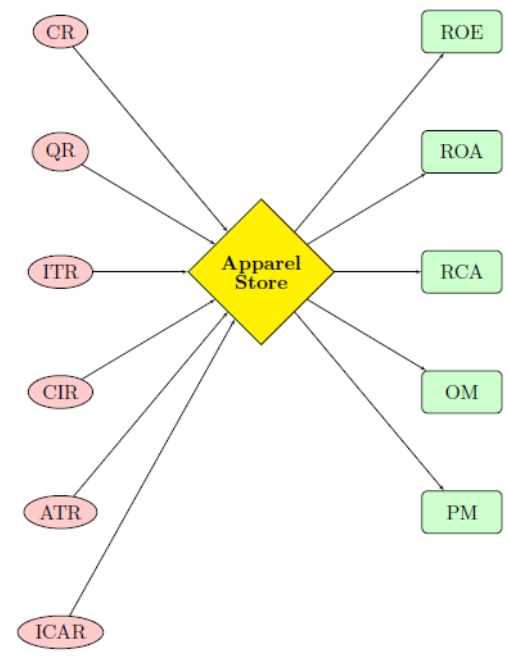

Figure 3. Schematic View of our Input and Output Analysis

Note. Firm's input variables appear on the left (red) and output parameters appear on the right (green), respectively.

As presented in Figure 3, our input variables include liquidity ratios such as current ratio (CR) and quick ratio (QR), and activity ratios including inventory turnover ratio (ITR), capital intensity ratio (CIR), accounts receivable turnover ratio (ARTR), and inventory-to-current assets ratio (ICAR) (Note 2). Our output variables are mainly operational profitability measures including return on equity (ROE) which measures amount of profits firm generates with shareholders investments, return on assets (ROA) which measures asset use efficiency, return on current assets (RCA) measures firm's efficiency in the use of their current assets to generate profits, operating margin $(\mathrm{OM})$ measures the effectiveness of a firm's pricing strategy and operarational efficiency, and profit margin (PM) measures the firm's effiieincy in keeping their overall costs down, basically measuring the firm's ability to convert revenues into overall profit. The schematic summary of how the inputs relate to the output is presented in Figure 3. The results of our estimation scores are presented in section 4.

\subsubsection{Modelling the Relationship between Financial Efficiency and Executive Compensation}

For our second stage, we analyze the relationship between CEO pay and financial efficiency of the 21 publicly traded US apparel stores as presented in Equation 7.

$$
\ln \left(\text { Pay }_{\mathrm{it}}\right)=\alpha_{\mathrm{i}}+\beta_{1} \mathrm{EFF}_{\mathrm{igt}}+\beta_{\mathrm{it}} \mathrm{X}_{\mathrm{iht}}+\varepsilon_{\mathrm{it}}
$$

where Pay $_{i t}$ is firm i's CEO compensation at time $t$, and $\alpha_{i}$ is the time-invariant unobservable firm-specific effects, such as firm-specific culture amongst others. $\mathrm{EFF}_{\text {igt }}$ denotes firm i's type $\mathrm{g}$ efficiency score at time $\mathrm{t}$, $\mathrm{X}_{\mathrm{iht}}$ denotes type $\mathrm{h}$ control variable for firm $\mathrm{i}$ at time $\mathrm{t}$, and $\varepsilon_{\mathrm{it}}$ is the time varying error term.

We employ the natural log of the overall annual CEO compensation as our dependent variable. Our variables of interest are the firm level financial efficiency scores $\left(\mathrm{EFF}_{\mathrm{igt}}\right.$, both static and dynamic specifications) as described in the previous section. Our static efficiency scores are the annual efficiency levels computed using both CRS $\left(\mathrm{EFF}_{\mathrm{i}, \mathrm{CRS}, \mathrm{t}}\right)$ and VRS $\left(\mathrm{EFF}_{\mathrm{i}, \mathrm{VRS}, \mathrm{t}}\right)$ assumptions. Our dynamic efficiency scores are the annual changes in firm's total factor productivity $\left(\mathrm{EFF}_{\mathrm{i}, \mathrm{TFP}, \mathrm{t}}\right)$ cumulated from the start of sample period (2004) to the year $\mathrm{t}$. We decompose this total factor productivity change score into technical efficiency change $\left(\mathrm{EFF}_{\mathrm{i}, \mathrm{EFFCH}, \mathrm{t}}\right)$ and technological change $\left(\mathrm{EFF}_{\mathrm{i}, \mathrm{TECHCH}, \mathrm{t}}\right)$. The technical efficiency change can further be decomposed into pure efficiency change $\left(\mathrm{EFF}_{\mathrm{i}, \mathrm{PECH}, \mathrm{t}}\right)$ and scale efficiency change $\left(\mathrm{EFF}_{\mathrm{i}, \mathrm{SECH}, \mathrm{t}}\right)$. The cumulative dynamic efficiency scores are computed as follows:

$$
\mathrm{CEFF}_{\mathrm{igt}}=\left(\prod_{\tau=2004}^{\mathrm{t}}\left(1+\mathrm{EFF}_{\mathrm{igt}}\right)\right)-1,
$$

where $\mathrm{CEFF}_{\text {igt }}$ is the cumulative dynamic efficiency scores, $\mathrm{EFF}_{\mathrm{igt}}$ is the year-to-year changes in dynamic efficiency scores, and $\mathrm{g}=\{\mathrm{TFP}, \mathrm{EFFCH}, \mathrm{TECHCH}, \mathrm{PECH}, \mathrm{SECH}\}$ denotes the individual efficiency categories.

We follow existing literature to select the most regularly used control variables which in our case includes firm size, CEO tenure, market performance, and firm-level risk. Following previous studies such as Bloom and 
Milkovich (1998) amongst others, we use the log of total assets (TA) as the proxy for firm size. Several previous studies have indicated that firm size is one of the most critical determinants of executive compensation (e.g. Finkelstein \& Hambrick, 1989; Paul \& Sahni, 2017); we, therefore, expect a positive and significant relationship between firm size and CEO pay. For robustness check purposes, we rerun our models using the log of the number of employees as a measurement of firm size. CEO tenure, a proxy for work experience, is measured as the number of years the CEO has held the position with a company and is computed as the difference between the date of becoming CEO and July $1^{\text {st }}$ of each firm-year. To test for non-linearity in the impact of tenure on compensation, we include tenure-squared. Some previous studies have argued that CEO tenure can serve as a proxy for CEO power, because longevity at post may lead to control over company board which may translate into entrenchment (Finkelstein \& Hambrick, 1989; Berrone \& Gomez-Mejia, 2009). However, CEO pay may increase with tenure for other reasons including the fact that the CEO gains valuable experience while on the job and may be compensated for that incremental gain in knowledge.

Several prior studies investigating determinants of CEO compensation including Shaw and Zhang (2010) have used stock market return as their proxy for firm performance. Since our efficiency analysis only focuses on internal operational efficiency, we didn't include any market measures of performance in our efficiency estimation. We, therefore, find it apropos to include measures of market performance as a control variable in our explanation of CEO compensation. As such, we include one-year and two-year firm stock price returns as control variables. Our one-year and two-year returns are computed from Bloomberg yearly price files. We thus calculate our one-year return as $R_{t 1}=\left(P_{t} / P_{t-1}\right)-1$, and our two-year return as $R_{t 2}=\left(P_{t} / P_{t-2}\right)-1$. Some previous studies have analyzed the effect of firm-risk on CEO compensation, for example from their natural experiment Gormley, Matsa, and Milbourn (2013) argues that boards respond quickly to changes in their firms' business risk by adjusting the structure of CEOs' compensation, but that the changes only slowly impact the overall portfolio incentives CEOs face. We control for firm-level risk by including idiosyncratic risk to our model which we calculate as the average annual variance of monthly returns computed over the previous 60 months (5 years). Variance is the squared error term obtained from the Carhart four-factor model. Lastly, recall that we were unable to include leverage measures in our efficiency estimations, however, since leverage is an essential component of the firm financing process, we chose to include long-term debt ratio (long-term debt/total assets) as a proxy for leverage in our CEO compensation model.

Table 1 presents the summary statistics for the analysis variables used in this study, including mean and median values. The absolute difference between the mean and median values generally indicates the skewness of a variable. For all our study variables, this difference is always less than one standard deviation $(\sigma)$, and ranges between $0.01 \times \sigma$ (for Operating Margin) and $0.54 \times \sigma$ (for Long-term debt). Therefore, one can safely assume that the distributions of the variables are fairly symmetrical.

Table 1. Variable Description and Summary Statistics

\begin{tabular}{llrrrrrr}
\hline & Mnemonic & Obs. & Mean & Median & Std & Min & Max \\
\hline Inputs: & & & & & & & \\
Current ratio & crs & 252 & 2.435 & 2.196 & 1.028 & 0.671 & 7.483 \\
Quick ratio & qr & 252 & 1.091 & 0.880 & 0.927 & 0.035 & 6.416 \\
Inventory turnover ratio & itr & 252 & 4.889 & 4.559 & 1.947 & 1.985 & 11.266 \\
Capital intensity ratio & cir & 252 & 0.536 & 0.510 & 0.149 & 0.235 & 1.150 \\
Accounts receivables turnover ratio & artr & 252 & 74.348 & 62.670 & 61.830 & 0.000 & 289.677 \\
Inventory-to-Current Assets & icar & 252 & 0.500 & 0.480 & 0.184 & 0.095 & 0.906 \\
& & & & & & & \\
Outputs: & & & & & & & \\
Return on assets & roa & 252 & 0.077 & 0.093 & 0.113 & -0.415 & 0.326 \\
Return on equity & roe & 252 & 0.145 & 0.156 & 0.246 & -1.181 & 1.054 \\
Return on current assets & roca & 252 & 0.125 & 0.147 & 0.214 & -0.952 & 0.593 \\
Operating margin & om & 252 & 0.072 & 0.071 & 0.070 & -0.173 & 0.230 \\
Profit margin & pm & 252 & 0.039 & 0.044 & 0.057 & -0.246 & 0.146 \\
& & & & & & & \\
Controls: & & & & & & & \\
Total assets (in billions) & ta & 252 & 2.056 & 0.932 & 2.503 & 0.179 & 11.490 \\
No. of employees (in thousands) & nemp & 252 & 23.672 & 8.188 & 43.601 & 0.941 & 216.000 \\
Idiosyncratic risk & idiorisk & 252 & 0.016 & 0.010 & 0.022 & 0.000 & 0.203 \\
One-year return & 1yrret & 252 & 0.170 & 0.091 & 0.745 & -0.900 & 8.434 \\
Two-year return & 2yrret & 252 & 0.409 & 0.272 & 1.059 & -0.969 & 8.115 \\
Long term debt/TA & ltdebt & 252 & 0.087 & 0.013 & 0.138 & 0.000 & 0.744 \\
Total Debt/TA & tdebt & 252 & 0.472 & 0.443 & 0.180 & 0.169 & 1.168 \\
Total CEO pay (in millions) & pay & 252 & 6.997 & 4.865 & 6.608 & 0.368 & 48.069 \\
Tenure as a CEO (in years) & tenure & 252 & 8.452 & 5.232 & 10.283 & 0.000 & 52.496 \\
\hline
\end{tabular}


Next, in order to check for the correlations between our input and output variables, we run pairwise correlations for our variables, results of which are presented in Table 2.

Table 2. Correlation matrix

\begin{tabular}{|c|c|c|c|c|c|c|c|c|c|c|c|}
\hline & & $\mathrm{qr}$ & itr & artr & cir & icar & roa & roe & roca & om & $\mathrm{pm}$ \\
\hline cr & 1.000 & & & & & & & & & & \\
\hline $\mathrm{qr}$ & $\begin{array}{l}0.879^{\star \star \star} \\
(0.000)\end{array}$ & 1.000 & & & & & & & & & \\
\hline itr & $\begin{array}{c}0.106^{\star} \\
(0.092)\end{array}$ & $\begin{array}{l}0.387^{\star \star \star} \\
(0.000)\end{array}$ & 1.000 & & & & & & & & \\
\hline artr & $\begin{array}{c}0.050 \\
(0.434)\end{array}$ & $\begin{array}{c}0.061 \\
(0.334)\end{array}$ & $\begin{array}{c}-0.104^{\star} \\
(0.099)\end{array}$ & 1.000 & & & & & & & \\
\hline cir & $\begin{array}{l}0.537^{\star \star \star} \\
(0.000)\end{array}$ & $\begin{array}{l}0.587^{\star \star \star} \\
(0.000)\end{array}$ & $\begin{array}{l}-0.079 \\
(0.209)\end{array}$ & $\begin{array}{l}-0.088 \\
(0.165)\end{array}$ & 1.000 & & & & & & \\
\hline icar & $\begin{array}{l}-0.460^{\star \star \star} \\
(0.000)\end{array}$ & $\begin{array}{l}-0.746^{\star \star \star} \\
(0.000)\end{array}$ & $\begin{array}{l}-0.603^{\star \star \star} \\
(0.000)\end{array}$ & $\begin{array}{c}0.082 \\
(0.196)\end{array}$ & $\begin{array}{l}-0.498^{\star \star \star} \\
(0.000)\end{array}$ & 1.000 & & & & & \\
\hline roa & $\begin{array}{c}0.136^{\star \star} \\
(0.031)\end{array}$ & $\begin{array}{l}0.209^{\star \star \star} \\
(0.001)\end{array}$ & $\begin{array}{c}0.053 \\
(0.402)\end{array}$ & $\begin{array}{l}0.279^{\star \star \star \star} \\
(0.000)\end{array}$ & $\begin{array}{c}0.030 \\
(0.635)\end{array}$ & $\begin{array}{l}-0.233^{\star \star \star} \\
(0.000)\end{array}$ & 1.000 & & & & \\
\hline roe & $\begin{array}{c}0.020 \\
(0.750)\end{array}$ & $\begin{array}{c}0.094 \\
(0.137)\end{array}$ & $\begin{array}{c}0.070 \\
(0.270)\end{array}$ & $\begin{array}{l}0.227^{\star \star \star} \\
(0.000)\end{array}$ & $\begin{array}{l}-0.021 \\
(0.740)\end{array}$ & $\begin{array}{l}-0.156^{\star \star} \\
(0.013)\end{array}$ & $\begin{array}{l}0.876^{\star \star \star} \\
(0.000)\end{array}$ & 1.000 & & & \\
\hline roca & $\begin{array}{c}0.095 \\
(0.134)\end{array}$ & $\begin{array}{c}0.158^{\star \star} \\
(0.012)\end{array}$ & $\begin{array}{c}0.007 \\
(0.916)\end{array}$ & $\begin{array}{l}0.245^{\star \star \star} \\
(0.000)\end{array}$ & $\begin{array}{c}0.090 \\
(0.154)\end{array}$ & $\begin{array}{l}-0.212^{\star \star \star} \\
(0.001)\end{array}$ & $\begin{array}{l}0.974^{\star \star \star} \\
(0.000)\end{array}$ & $\begin{array}{l}0.870^{\star \star \star} \\
(0.000)\end{array}$ & 1.000 & & \\
\hline om & $\begin{array}{l}0.263^{\star \star \star \star} \\
(0.000)\end{array}$ & $\begin{array}{l}0.364^{\star \star \star} \\
(0.000)\end{array}$ & $\begin{array}{c}0.082 \\
(0.192)\end{array}$ & $\begin{array}{l}0.232^{\star \star \star \star} \\
(0.000)\end{array}$ & $\begin{array}{l}0.235^{\star \star \star} \\
(0.000)\end{array}$ & $\begin{array}{l}-0.388^{\star \star \star \star} \\
(0.000)\end{array}$ & $\begin{array}{l}0.904^{\star \star \star} \\
(0.000)\end{array}$ & $\begin{array}{l}0.764^{\star \star \star} \\
(0.000)\end{array}$ & $\begin{array}{l}0.896^{\star \star \star} \\
(0.000)\end{array}$ & 1.000 & \\
\hline $\mathrm{pm}$ & $\begin{array}{l}0.244^{\star \star \star} \\
(0.000)\end{array}$ & $\begin{array}{l}0.319^{\star \star \star \star} \\
(0.000)\end{array}$ & $\begin{array}{c}0.026 \\
(0.679)\end{array}$ & $\begin{array}{l}0.222^{\star \star \star \star} \\
(0.000)\end{array}$ & $\begin{array}{l}0.185^{\star \star \star \star} \\
(0.003)\end{array}$ & $\begin{array}{l}-0.319^{\star \star \star \star} \\
(0.000)\end{array}$ & $\begin{array}{l}0.950^{\star \star \star} \\
(0.000)\end{array}$ & $\begin{array}{l}0.808^{\star \star \star \star} \\
(0.000)\end{array}$ & $\begin{array}{l}0.949^{\star \star \star} \\
(0.000)\end{array}$ & $\begin{array}{l}0.937^{\star \star \star} \\
(0.000)\end{array}$ & 1.000 \\
\hline
\end{tabular}

Note. P-values in parentheses $(* p<0.10, * * p<0.05, * * * p<0.01)$

From Table 2, we can conclude that our output variables are very highly correlated, but not with the input variables. In the case of the correlation between our input variables, however, we have a mixed bag of outcomes. While we find a high positive correlation between current ratio and quick ratio, we also find a high negative correlation between inventory-to-current assets ratio and each of the following ratios: quick ratio and inventory turnover ratio.

\section{Empirical Results}

\subsection{Productivity and Efficiency of the US Apparel Stores Industry}

In our first stage analysis, we calculate DEA type annual efficiency scores for our 21 firms. We find that six out of the 21 firms including ARO Liquidation Inc., TJX Cos Inc., Bebe Stores Inc., Buckle Inc., Pacific Sunwear of California Inc., and Stein Mart Inc., were the only firms that were on the efficiency frontier at the beginning of our study period.

Next, we turn our attention to the results of the total factor productivity (TFP) estimation. Here, we must recall that the TFP can be broken down into technological change (TECHCH) and technical efficiency change $(\mathrm{EFFCH})$. And, the technical efficiency change $(\mathrm{EFFCH})$ can further be decomposed into scale efficiency change (SECH) and pure efficiency change (PECH). We find that for the period under consideration publicly traded US apparel stores experienced a 1.03\% decline in TFP, 3.39\% improvement in EFFCH ("catch-up" effect), $4.20 \%$ decline in TECHCH, 3.75\% improvement in PECH and a $0.37 \%$ decline in SECH. This result is indicative of the fact that the overall decrease in the total factor productivity of these firms for the period under investigation can be largely attributed to the technological change drop. The top 5 highest average total productivity gains were experienced by Foot Locker Inc. (15.03\%), Carter's Inc. (9.24\%), Ross Stores Inc. (9.11\%), Destination XL Group Inc. (8.06\%), and Ann Inc. (4.50\%). Conversely, the lowest five total factor productivity firms are Bebe Stores Inc. (-31.56\%), Pacific Sunwear of California Inc. (-10.87\%), Stein Mart Inc. (-9.35\%), Buckle Inc. (-8.96\%), and Abercrombie \& Fitch Co. (-7.21\%). About technical efficiency change, Foot Locker Inc. recorded the highest average growth $(18.89 \%)$, whereas L Brands Inc. (3.86\%) recorded the highest average technological change. Regarding pure efficiency change and scale efficiency change, Foot Locker Inc. (17.85\%), and American Eagle Outfitters Inc. (1.34\%) recorded the highest average growth rates respectively. The worst performing firms in each category include Pacific Sunwear of California Inc. (-8.30\%) for EFFCH, Bebe Stores Inc. (-31.56\%) for TECHCH, Abercrombie \& Fitch Co. (-6.90\%) for PECH and Pacific Sunwear of California Inc. $(-3.82 \%)$ for SECH. The summary statistics of our efficiency estimates are presented in Table 3. 
Table 3. Efficiency Scores Estimates Summary Statistics

\begin{tabular}{llllllll}
\hline & Mnemonic & Obs. & Mean & Median & Std & Min & Max \\
\hline $\begin{array}{l}\text { Static: } \\
\text { Constant returns to scale }\end{array}$ & CRS & 252 & 0.945 & 0.973 & 0.064 & 0.682 & 1.000 \\
Variable returns to scale & VRS & 252 & 0.958 & 0.993 & 0.054 & 0.769 & 1.000 \\
& & & & & & & \\
Dynamic: & & & & & & & \\
Total factor productivity & TFPCH & 252 & 0.990 & 1.000 & 0.122 & 0.427 & 1.308 \\
$\quad$ * Technical efficiency change & EFFCH & 252 & 1.034 & 1.010 & 0.086 & 0.817 & 1.277 \\
$\quad$ Pure efficiency change & PECH & 252 & 1.037 & 1.000 & 0.081 & 0.819 & 1.262 \\
$\quad$ Scale efficiency change & SECH & 252 & 0.996 & 1.000 & 0.021 & 0.872 & 1.025 \\
$*$ Technology change & TECHCH & 252 & 0.958 & 0.970 & 0.096 & 0.427 & 1.217 \\
\hline
\end{tabular}

To analyze how firms have performed over time in comparison to the beginning of our study period in terms of total factor productivity, we combine our DEA type CRS productivity score for each firm in 2004 with the cumulative efficiency growth in TFP for the period under consideration from which we created the $2 \times 2$ matrix (see Figure 4).

\begin{tabular}{lll} 
& $\sum_{t=2}^{n} \mathrm{TFP}_{i}>\sum_{t=2}^{n} \mathrm{TFP}$ & $\sum_{t=2}^{n} \mathrm{TFP}_{i} \leq \sum_{t=2}^{n} \mathrm{TFP}$ \\
$C R S_{i, t=1}=1$ & AROPQ, TJX & BEBE, BKE, PSUNQ, SMRT \\
$C R S_{i, t=1}<1$ & $\begin{array}{l}\text { ANN, CATO, CRI, DXLG, FINL, FL, } \\
\text { GPS, LB, PLCE, ROST }\end{array}$ & AEO, ANF, CAL, DEST, GCO \\
\hline
\end{tabular}

Figure 4. Comparative Efficiency Performance of firms in the sample (2004-2015)

Note. The row delineates efficient firms in 2004 from non-efficient firms, whereas, the columns separate higher than average cumulative growth firms from their lower than average growth compatriots.

The rows of Figure 4 differentiate between efficient and inefficient firms in 2004, whereas the columns measure whether a firm recorded more than sample average cumulative TFP growth for the 2004-2015 period. Thus, the firms in the upper left portion of the matrix are the ones who were efficient in 2004 and recorded a cumulative growth rate that is higher than the average for sample firms for the period under consideration. We label these firms "trendsetters." We label the firms the top right portion of the matrix "falling stars." These firms are the ones that were efficient in 2004 but experienced below average cumulative efficiency growth for the study period. Located in the bottom left of the matrix are firms who were inefficient in 2004 but has recorded higher than average cumulative growth rates in efficiency during our study period. We have labeled these firms "shooting stars." Conversely, firms located in the bottom right of our matrix which we label "the strugglers" are firms who were inefficient at the beginning of our study period and recorded less than average cumulative growth rates.

\subsection{CEO Compensation and Efficiency}

\subsubsection{CEO Compensation Base Case}

We model CEO compensation with a pooled cross-sectional regression with year fixed-effects. Our main focus is to examine how efficiency (and cumulative changes in efficiency) impacts CEO compensation while controlling for firm size, firm stock price returns, CEO tenure, and idiosyncratic risk. Our main results are presented in Tables 4 and 5. Table 4 presents our estimation models without correcting for leverage, whereas Table 5 corrects for the impact of financial leverage on executive compensation, by employing total debt ratio as the leverage proxy.

Model 1 in Tables 4 and 5 presents our base models without firm efficiency. As such they control for frequently used variables in existing literature to explain executive compensation such as firm size, stock market return, executive tenure, and risks. Jensen (1986) and Williamson (1988) postulate that debt may indicate the need for additional monitoring, thus, further complicating the duties of the CEO and as such deserving additional compensation. However, interestingly we find a negative but insignificant relationship between leverage and 
CEO compensation, a result which is similar to Bryan, Hwang, Klein, and Lilien (2000). Even though we find positive relationships between our stock returns proxies and CEO compensation, and between idiosyncratic risk and CEO compensation, we find that these variables do not have a significant impact on the determination of the compensation that CEOs of US apparel firms receive. The coefficient for tenure is positive and significant in all model specifications. We find between 2.08\% (Table 5) and 3.25\% (Table 4) increase in CEO compensation for every additional year spent in the job. This finding indicates that the firms reward longer serving executives with higher pay than newer CEOs (Gibbons \& Murphy, 1992; Paul \& Sahni, 2017). Alternatively, some scholars (e.g. Hermalin \& Weisbach, 1998) argue that the CEO's influence over board members increases with tenure and may lead to "self-dealing."

Table 4. Total Compensation and Efficiency

\begin{tabular}{|c|c|c|c|c|c|c|c|}
\hline & Model 1 & Model 2 & Model 3 & Model 4 & Model 5 & Model 6 & Model 7 \\
\hline \multicolumn{8}{|l|}{ Efficiency: } \\
\hline CRS & & $\begin{array}{l}1.7203^{\star \star \star \star} \\
(0.6621)\end{array}$ & & & & & \\
\hline VRS & & & $\begin{array}{l}2.1149^{\star \star \star \star} \\
(0.8057)\end{array}$ & & & & \\
\hline TFPCH & & & & $\begin{array}{c}0.8775^{\star} \\
(0.4892)\end{array}$ & & & \\
\hline EFFCH & & & & & $\begin{array}{c}0.3198 \\
(0.5479)\end{array}$ & & \\
\hline TECHCH & & & & & $\begin{array}{c}1.3224^{\star} \\
(0.7481)\end{array}$ & & $\begin{array}{l}1.5701^{\star \star} \\
(0.7101)\end{array}$ \\
\hline PECH & & & & & & $\begin{array}{l}-0.2543 \\
(0.6196)\end{array}$ & $\begin{array}{l}-0.1720 \\
(0.6038)\end{array}$ \\
\hline SECH & & & & & & $\begin{array}{l}5.0399^{\star \star} \\
(2.2027)\end{array}$ & $\begin{array}{l}6.3077^{\star \star \star \star} \\
(2.1919)\end{array}$ \\
\hline \multicolumn{8}{|l|}{ Controls: } \\
\hline $\ln (\mathrm{ta})$ & $\begin{array}{l}0.5660^{\star \star \star} \\
(0.0446)\end{array}$ & $\begin{array}{l}0.5556^{\star \star \star \star} \\
(0.0478)\end{array}$ & $\begin{array}{l}0.5588^{\star \star \star \star} \\
(0.0473)\end{array}$ & $\begin{array}{l}0.5434^{\star \star \star \star} \\
(0.0461)\end{array}$ & $\begin{array}{l}0.5285^{\star \star \star \star} \\
(0.0448)\end{array}$ & $\begin{array}{l}0.5504^{\star \star \star} \\
(0.0484)\end{array}$ & $\begin{array}{l}0.5014^{\star \star \star} \\
(0.0449)\end{array}$ \\
\hline 1yrret & $\begin{array}{l}-0.0185 \\
(0.1434)\end{array}$ & $\begin{array}{l}-0.0314 \\
(0.1457)\end{array}$ & $\begin{array}{l}-0.0246 \\
(0.1418)\end{array}$ & $\begin{array}{l}-0.0564 \\
(0.1397)\end{array}$ & $\begin{array}{c}-0.0498 \\
(0.1414)\end{array}$ & $\begin{array}{l}-0.0433 \\
(0.1524)\end{array}$ & $\begin{array}{c}-0.0795 \\
(0.1427)\end{array}$ \\
\hline 2 yrret & $\begin{array}{c}0.1084 \\
(0.0671)\end{array}$ & $\begin{array}{c}0.0902 \\
(0.0666)\end{array}$ & $\begin{array}{c}0.0898 \\
(0.0654)\end{array}$ & $\begin{array}{c}0.0847 \\
(0.0638)\end{array}$ & $\begin{array}{c}0.0873 \\
(0.0633)\end{array}$ & $\begin{array}{c}0.1019 \\
(0.0670)\end{array}$ & $\begin{array}{c}0.0791 \\
(0.0616)\end{array}$ \\
\hline idiorisk & $\begin{array}{c}0.7983 \\
(3.4100)\end{array}$ & $\begin{array}{c}1.0682 \\
(3.5091)\end{array}$ & $\begin{array}{c}0.7129 \\
(3.2918)\end{array}$ & $\begin{array}{c}1.9285 \\
(3.3245)\end{array}$ & $\begin{array}{c}1.4768 \\
(3.3504)\end{array}$ & $\begin{array}{c}1.8827 \\
(3.7121)\end{array}$ & $\begin{array}{c}2.6700 \\
(3.6094)\end{array}$ \\
\hline tenure & $\begin{array}{l}0.0310^{\star \star} \\
(0.0135)\end{array}$ & $\begin{array}{l}0.0323^{\star \star} \\
(0.0130)\end{array}$ & $\begin{array}{l}0.0325^{\star \star} \\
(0.0137)\end{array}$ & $\begin{array}{l}0.0278^{\star \star} \\
(0.0138)\end{array}$ & $\begin{array}{l}0.0271^{\star \star} \\
(0.0135)\end{array}$ & $\begin{array}{l}0.0290^{\star \star} \\
(0.0134)\end{array}$ & $\begin{array}{c}0.0242^{\star} \\
(0.0129)\end{array}$ \\
\hline tenure $^{2}$ & $\begin{array}{l}-0.0006^{\star *} \\
(0.0003)\end{array}$ & $\begin{array}{l}-0.0006^{\star \star *} \\
(0.0003)\end{array}$ & $\begin{array}{l}-0.0006^{\star *} \\
(0.0003)\end{array}$ & $\begin{array}{l}-0.0006^{\star \star} \\
(0.0003)\end{array}$ & $\begin{array}{l}-0.0006^{\star \star \star} \\
(0.0003)\end{array}$ & $\begin{array}{l}-0.0006^{\star \star} \\
(0.0003)\end{array}$ & $\begin{array}{r}-0.0005^{\star} \\
(0.0003)\end{array}$ \\
\hline Constant & $\begin{array}{l}-3.4584^{\star \star \star \star} \\
(0.3869)\end{array}$ & $\begin{array}{l}-4.9555^{\star \star \star \star} \\
(0.6140)\end{array}$ & $\begin{array}{l}-5.3567^{\star \star \star \star} \\
(0.7446)\end{array}$ & $\begin{array}{l}-4.1409^{\star \star \star} \\
(0.6095)\end{array}$ & $\begin{array}{l}-4.7949^{\star \star \star \star} \\
(1.0613)\end{array}$ & $\begin{array}{l}-8.1286^{\star \star \star \star} \\
(2.1114)\end{array}$ & $\begin{array}{c}-10.6565^{\star \star \star \star} \\
(2.3919)\end{array}$ \\
\hline $\mathrm{N}$ & 252 & 252 & 252 & 252 & 252 & 252 & 252 \\
\hline Year FE & Yes & Yes & Yes & Yes & Yes & Yes & Yes \\
\hline Adj. $R^{2}$ & 0.4913 & 0.5021 & 0.5029 & 0.4994 & 0.5010 & 0.4984 & 0.5153 \\
\hline
\end{tabular}

Note. Standard errors in parentheses. *** $\mathrm{p}<0.01$, ** $\mathrm{p}<0.05$, * $\mathrm{p}<0.1$. Controls include the natural logarithm of total assets [ $\ln (\mathrm{ta})]$, one-year stock returns [1yrret], two-year stock returns [2yrret], idiosyncratic risk [idiorisk], and CEO tenure [tenure] and its squared term [tenure ${ }^{2}$.

We now turn our attention to our primary variable of interest - firm financial efficiency. In Table 4, we find that annual efficiency levels (CRS and VRS) are positive and significant. Specifically, we find that a one percent increase in efficiency scores translates to about $1.72 \%$ (Model 2) and $2.11 \%$ (Model 3) increase in CEO compensation. In comparison, Paul and Sahni (2017) document that a one percent increase in return on assets is associated with about $0.71 \%$ increase in CEO pay. Model 2 is used for expository purposes. For the CEO with the sample mean annual pay ( $\$ 6.997$ million), a one percent increase in CRS efficiency is associated with about $\$ 120000$ increase in CEO pay.

We also find that the cumulative total factor productivity (TFP) is positive and significant, indicating that a one percent increase in TFP translates to about $0.88 \%$ improvement in CEO compensation. Further, we find that a sizable impact of TFP stems from the cumulative technological change (TECHCH). Cumulative technical efficiency change (EFFCH) is not significant. Interestingly though when we disaggregate EFFCH into pure efficiency change (PECH) ("catch up effect") and scale efficiency change (SECH), we find a significantly 
positive relationship between SECH and CEO compensation. A one percent increase in SECH translates to between 5.04\% (Model 6) and 6.31\% (Model 7) increase in CEO pay.

Table 5. Total Compensation, Efficiency and Leverage

\begin{tabular}{|c|c|c|c|c|c|c|c|}
\hline & Model 1 & Model 2 & Model 3 & Model 4 & Model 5 & Model 6 & Model 7 \\
\hline $\begin{array}{l}\text { Efficiency: } \\
\text { CRS }\end{array}$ & & $\begin{array}{l}1.7525^{\star \star} \\
(0.6899)\end{array}$ & & & & & \\
\hline VRS & & & $\begin{array}{l}2.1563^{\star \star} \\
(0.8546)\end{array}$ & & & & \\
\hline TFPCH & & & & $\begin{array}{c}0.9450^{\star} \\
(0.4934)\end{array}$ & & & \\
\hline EFFCH & & & & & $\begin{array}{c}0.3562 \\
(0.5392)\end{array}$ & & \\
\hline TECHCH & & & & & $\begin{array}{l}1.4573^{\star \star} \\
(0.7387)\end{array}$ & & $\begin{array}{l}1.6634^{\star \star} \\
(0.7675)\end{array}$ \\
\hline PECH & & & & & & $\begin{array}{l}-0.2561 \\
(0.6173)\end{array}$ & $\begin{array}{l}-0.1327 \\
(0.6175)\end{array}$ \\
\hline SECH & & & & & & $\begin{array}{l}5.0498^{\star \star} \\
(2.2891)\end{array}$ & $\begin{array}{l}6.1895^{\text {}}(2.1762) \\
(2.15\end{array}$ \\
\hline Controls: & & & & & & & \\
\hline $\ln (\mathrm{ta})$ & $\begin{array}{l}0.5672^{\star \star \star} \\
(0.0463)\end{array}$ & $\begin{array}{l}0.5543^{\star \star \star \star} \\
(0.0472)\end{array}$ & $\begin{array}{l}0.5575^{\star \star \star \star} \\
(0.0487)\end{array}$ & $\begin{array}{l}0.5453^{\star \star \star} \\
(0.0459)\end{array}$ & $\begin{array}{l}0.5293^{\star \star \star \star} \\
(0.0452)\end{array}$ & $\begin{array}{l}0.5502^{\star \star \star \star} \\
(0.0471)\end{array}$ & $\begin{array}{l}0.5026^{\star \star \star} \\
(0.0441)\end{array}$ \\
\hline 1yrret & $\begin{array}{l}-0.0207 \\
(0.1423)\end{array}$ & $\begin{array}{l}-0.0297 \\
(0.1410)\end{array}$ & $\begin{array}{l}-0.0226 \\
(0.1453)\end{array}$ & $\begin{array}{l}-0.0657 \\
(0.1365)\end{array}$ & $\begin{array}{l}-0.0613 \\
(0.1456)\end{array}$ & $\begin{array}{l}-0.0430 \\
(0.1464)\end{array}$ & $\begin{array}{l}-0.0873 \\
(0.1447)\end{array}$ \\
\hline 2yrret & $\begin{array}{c}0.1084^{\star} \\
(0.0629)\end{array}$ & $\begin{array}{c}0.0898 \\
(0.0656)\end{array}$ & $\begin{array}{c}0.0894 \\
(0.0645)\end{array}$ & $\begin{array}{c}0.0829 \\
(0.0581)\end{array}$ & $\begin{array}{c}0.0851 \\
(0.0634)\end{array}$ & $\begin{array}{c}0.1019 \\
(0.0660)\end{array}$ & $\begin{array}{c}0.0777 \\
(0.0578)\end{array}$ \\
\hline idiorisk & $\begin{array}{c}0.9323 \\
(3.4124)\end{array}$ & $\begin{array}{c}0.9506 \\
(3.3392)\end{array}$ & $\begin{array}{c}0.5793 \\
(3.4340)\end{array}$ & $\begin{array}{c}2.4185 \\
(3.2667)\end{array}$ & $\begin{array}{c}2.0705 \\
(3.4184)\end{array}$ & $\begin{array}{c}1.8642 \\
(3.6414)\end{array}$ & $\begin{array}{c}3.0793 \\
(3.5264)\end{array}$ \\
\hline tdebt & $\begin{array}{l}-0.0709 \\
(0.3049)\end{array}$ & $\begin{array}{c}0.0649 \\
(0.3042)\end{array}$ & $\begin{array}{c}0.0698 \\
(0.3115)\end{array}$ & $\begin{array}{l}-0.2134 \\
(0.2981)\end{array}$ & $\begin{array}{l}-0.2754 \\
(0.3065)\end{array}$ & $\begin{array}{c}0.0104 \\
(0.3040)\end{array}$ & $\begin{array}{l}-0.2029 \\
(0.3064)\end{array}$ \\
\hline tenure & $\begin{array}{l}0.0308^{\star \star} \\
(0.0136)\end{array}$ & $\begin{array}{l}0.0325^{\star \star} \\
(0.0138)\end{array}$ & $\begin{array}{l}0.0327^{\star \star} \\
(0.0134)\end{array}$ & $\begin{array}{c}0.0270^{\star} \\
(0.0140)\end{array}$ & $\begin{array}{c}0.0260^{\star} \\
(0.0136)\end{array}$ & $\begin{array}{l}0.0291^{\star \star} \\
(0.0136)\end{array}$ & $\begin{array}{c}0.0235^{\star} \\
(0.0134)\end{array}$ \\
\hline tenure $^{2}$ & $\begin{array}{l}-0.0006^{\star \star} \\
(0.0003)\end{array}$ & $\begin{array}{l}-0.0006^{\star \star} \\
(0.0003)\end{array}$ & $\begin{array}{l}-0.0006^{\star \star} \\
(0.0003)\end{array}$ & $\begin{array}{r}-0.0005^{\star} \\
(0.0003)\end{array}$ & $\begin{array}{c}-0.0005^{\star} \\
(0.0003)\end{array}$ & $\begin{array}{l}-0.0006^{\star \star} \\
(0.0003)\end{array}$ & $\begin{array}{l}-0.0004 \\
(0.0003)\end{array}$ \\
\hline Constant & $\begin{array}{l}-3.4355^{\star \star \star} \\
(0.4273)\end{array}$ & $\begin{array}{l}-5.0045^{\star \star \star} \\
(0.6786)\end{array}$ & $\begin{array}{l}-5.4164^{\star \star \star \star} \\
(0.8468)\end{array}$ & $\begin{array}{l}-4.1245^{\star \star \star} \\
(0.5730)\end{array}$ & $\begin{array}{l}-4.8462^{\star \star \star} \\
(1.0417)\end{array}$ & $\begin{array}{l}-8.1398^{\star \star \star} \\
(2.2077)\end{array}$ & $\begin{array}{c}-10.5876^{\star \star \star \star} \\
(2.2787)\end{array}$ \\
\hline $\mathrm{N}$ & 252 & 252 & 252 & 252 & 252 & 252 & 252 \\
\hline Year FE & Yes & Yes & Yes & Yes & Yes & Yes & Yes \\
\hline Adj. $R^{2}$ & 0.4892 & 0.5001 & 0.5009 & 0.4985 & 0.5008 & 0.4962 & 0.5143 \\
\hline
\end{tabular}

Note. Standard errors in parentheses. $* * * \mathrm{p}<0.01, * * \mathrm{p}<0.05, * \mathrm{p}<0.1$. Controls include the natural logarithm of total assets [ $\ln (\mathrm{ta})]$, one-year stock returns [1yrret], two-year stock returns [2yrret], idiosyncratic risk [idiorisk], total debt-to-total assets [tdebt], and CEO tenure [tenure] and its squared term [tenure ${ }^{2}$.

Together, our results suggest that efficiency (profitability controlling for inputs) is a strong determinant of CEO pay indicating that a significant managerial talent is involved in efficiency improvements. All of our results hold after controlling for leverage (see Table 5).

\subsubsection{CEO Compensation Robustness Check}

Previous studies have sometimes used stock market capitalization, sales, net assets, and number of employees to proxy for firm size. Thus, one must consider whether the relationship between CEO compensation and efficiency is sensitive to the choice of firm size proxy. While the three accounting measures (market capitalization, sales, and net assets) are similar in spirit to total assets and captures the size effect that correlates with the firm's physical capital, number of employees captures size effect that reflects the firm's human capital. For robustness, we use number of employees. The reason for this is as follows: apparel industry, in general, is labor-intensive. Specifically, our sample of firms has an average employee strength well over 20000 , with a range of 1000 to 216000 (Table 1). Table 6 replicates Table 4 with the number of employees as the firm size proxy. 
Table 6. Total Compensation and Robustness

\begin{tabular}{|c|c|c|c|c|c|c|c|}
\hline & Model 1 & Model 2 & Model 3 & Model 4 & Model 5 & Model 6 & Model 7 \\
\hline \multicolumn{8}{|l|}{ Efficiency: } \\
\hline CRS & & $\begin{array}{l}2.5080^{\star \star \star} \\
(0.7178)\end{array}$ & & & & & \\
\hline VRS & & & $\begin{array}{l}3.0281^{\star \star \star \star} \\
(0.8513)\end{array}$ & & & & \\
\hline TFPCH & & & & $\begin{array}{l}1.2204^{\star \star} \\
(0.5546)\end{array}$ & & & \\
\hline EFFCH & & & & & $\begin{array}{c}0.3944 \\
(0.6881)\end{array}$ & & \\
\hline TECHCH & & & & & $\begin{array}{l}1.9065^{\star \star} \\
(0.7885)\end{array}$ & & $\begin{array}{l}2.2479^{\star \star \star} \\
(0.7744)\end{array}$ \\
\hline PECH & & & & & & $\begin{array}{l}-0.4019 \\
(0.7214)\end{array}$ & $\begin{array}{l}-0.3141 \\
(0.7032)\end{array}$ \\
\hline SECH & & & & & & $\begin{array}{l}7.0518^{\star \star \star} \\
(2.3958)\end{array}$ & $\begin{array}{l}8.7441^{\star \star \star} \\
(2.4393)\end{array}$ \\
\hline \multicolumn{8}{|l|}{ Controls: } \\
\hline $\ln ($ nemp $)$ & $\begin{array}{l}0.2661^{\star \star \star \star} \\
(0.0385)\end{array}$ & $\begin{array}{l}0.2676^{\star \star \star} \\
(0.0386)\end{array}$ & $\begin{array}{l}0.2725^{\text {}} \\
(0.0386)\end{array}$ & $\begin{array}{l}0.2414^{\star \star \star \star} \\
(0.0383)\end{array}$ & $\begin{array}{l}0.2199^{\star \star \star} \\
(0.0363)\end{array}$ & $\begin{array}{l}0.2548^{\star \star \star} \\
(0.0387)\end{array}$ & $\begin{array}{l}0.1964^{\star \star \star \star} \\
(0.0362)\end{array}$ \\
\hline 1yrret & $\begin{array}{c}0.0821 \\
(0.1701)\end{array}$ & $\begin{array}{c}0.0563 \\
(0.1638)\end{array}$ & $\begin{array}{c}0.0659 \\
(0.1646)\end{array}$ & $\begin{array}{c}0.0288 \\
(0.1609)\end{array}$ & $\begin{array}{c}0.0395 \\
(0.1546)\end{array}$ & $\begin{array}{c}0.0449 \\
(0.1725)\end{array}$ & $\begin{array}{l}-0.0052 \\
(0.1597)\end{array}$ \\
\hline 2 yrret & $\begin{array}{c}0.0532 \\
(0.0840)\end{array}$ & $\begin{array}{c}0.0293 \\
(0.0793)\end{array}$ & $\begin{array}{c}0.0292 \\
(0.0780)\end{array}$ & $\begin{array}{c}0.0218 \\
(0.0754)\end{array}$ & $\begin{array}{c}0.0260 \\
(0.0763)\end{array}$ & $\begin{array}{c}0.0467 \\
(0.0783)\end{array}$ & $\begin{array}{c}0.0177 \\
(0.0730)\end{array}$ \\
\hline idiorisk & $\begin{array}{c}-7.2363^{\star} \\
(4.3149)\end{array}$ & $\begin{array}{l}-6.3905 \\
(4.2867)\end{array}$ & $\begin{array}{l}-6.9031 \\
(4.4384)\end{array}$ & $\begin{array}{l}-5.4886 \\
(4.3380)\end{array}$ & $\begin{array}{l}-6.1194 \\
(4.5922)\end{array}$ & $\begin{array}{l}-5.4657 \\
(4.8704)\end{array}$ & $\begin{array}{l}-4.0944 \\
(4.6488)\end{array}$ \\
\hline tenure & $\begin{array}{c}0.0204 \\
(0.0156)\end{array}$ & $\begin{array}{c}0.0229 \\
(0.0152)\end{array}$ & $\begin{array}{c}0.0232 \\
(0.0156)\end{array}$ & $\begin{array}{c}0.0160 \\
(0.0165)\end{array}$ & $\begin{array}{c}0.0148 \\
(0.0149)\end{array}$ & $\begin{array}{c}0.0180 \\
(0.0154)\end{array}$ & $\begin{array}{c}0.0112 \\
(0.0143)\end{array}$ \\
\hline $\begin{array}{l}\text { tenure }{ }^{2} \\
\times 10^{-2}\end{array}$ & $\begin{array}{l}-0.0065 \\
(0.0003)\end{array}$ & $\begin{array}{l}-0.0087 \\
(0.0003)\end{array}$ & $\begin{array}{l}-0.0085 \\
(0.0003)\end{array}$ & $\begin{array}{c}0.0017 \\
(0.0003)\end{array}$ & $\begin{array}{l}-0.0003 \\
(0.0003)\end{array}$ & $\begin{array}{l}-0.0009 \\
(0.0003)\end{array}$ & $\begin{array}{c}0.0062 \\
(0.0003)\end{array}$ \\
\hline Constant & $\begin{array}{l}-1.7996^{\star \star \star} \\
(0.4449)\end{array}$ & $\begin{array}{l}-4.1097^{\star \star \star} \\
(0.6862)\end{array}$ & $\begin{array}{l}-4.6558^{\star \star \star} \\
(0.8651)\end{array}$ & $\begin{array}{l}-2.7462^{\star \star \star} \\
(0.6692)\end{array}$ & $\begin{array}{l}-3.6218^{\star \star \star} \\
(1.1648)\end{array}$ & $\begin{array}{l}-8.3432^{\star \star \star} \\
(2.2911)\end{array}$ & $\begin{array}{c}-11.7735^{\star \star \star} \\
(2.5550)\end{array}$ \\
\hline $\mathrm{N}$ & 252 & 252 & 252 & 252 & 252 & 252 & 252 \\
\hline Year FE & Yes & Yes & Yes & Yes & Yes & Yes & Yes \\
\hline Adj. $R^{2}$ & 0.3103 & 0.3352 & 0.3357 & 0.3272 & 0.3325 & 0.3272 & 0.3622 \\
\hline
\end{tabular}

Note. Standard errors in parentheses. $* * * \mathrm{p}<0.01, * * \mathrm{p}<0.05, * \mathrm{p}<0.1$. Controls include the natural logarithm of number of employees [ $\ln (\mathrm{nemp})]$, one-year stock returns [1yrret], two-year stock returns [2yrret], idiosyncratic risk [idiorisk], and CEO tenure [tenure] and its squared term [tenure ${ }^{2}$ ].

Table 7 replicates Table 5 with the number of employees as the firm size proxy. In this table, leverage proxied by total debt ratio is used as an additional control variable.

In both tables (Tables 6 and 7), we find the strengthening of the original relationship between efficiency and CEO pay. Model 2 is used for expository purposes. For the CEO with the sample mean annual pay ( $\$ 6.997$ million), a one percent increase in CRS efficiency is associated with about $\$ 175000$ increase in CEO pay. In comparison, the same model specification in Table 4 yielded about $\$ 120000$ increase in CEO pay. The most parsimonious explanation for this result may be that the explanatory power of total assets on CEO pay is absolute, limiting the influence of other pay characteristics. As a consequence, removing total assets from model specifications may play an active role in enhancing the relative importance of different variables - in our case, the efficiency scores. Here, we can also note the relative importance of firm size proxies (book value of assets and number of employees) in explaining CEO pay. The size effect, proxied by the number of employees in Table 6 (Coefficient: 0.2661 ), on CEO pay is approximately half the size effect of total assets reported in Table 4 (Coefficient: 0.5660 ), yet highly significant. 
Table 7. Total Compensation and Robustness (with Leverage)

\begin{tabular}{|c|c|c|c|c|c|c|c|}
\hline & Model 1 & Model 2 & Model 3 & Model 4 & Model 5 & Model 6 & Model 7 \\
\hline \multicolumn{8}{|l|}{ Efficiency: } \\
\hline CRS & & $\begin{array}{l}2.3464^{\star \star \star} \\
(0.7635)\end{array}$ & & & & & \\
\hline VRS & & & $\begin{array}{l}2.8404^{\star \star \star} \\
(0.9609)\end{array}$ & & & & \\
\hline TFPCH & & & & $\begin{array}{l}1.3858^{\star \star \star} \\
(0.5168)\end{array}$ & & & \\
\hline EFFCH & & & & & $\begin{array}{c}0.5132 \\
(0.6489)\end{array}$ & & \\
\hline ТЕCHCH & & & & & $\begin{array}{l}2.1464^{\star \star \star} \\
(0.7841)\end{array}$ & & $\begin{array}{l}2.4142^{\star \star \star} \\
(0.7661)\end{array}$ \\
\hline PECH & & & & & & $\begin{array}{c}-0.3062 \\
(0.7341)\end{array}$ & $\begin{array}{l}-0.1640 \\
(0.6903)\end{array}$ \\
\hline SECH & & & & & & $\begin{array}{l}6.6155^{\star \star} \\
(2.6294)\end{array}$ & $\begin{array}{l}8.2149^{\star \star \star \star} \\
(2.4970)\end{array}$ \\
\hline \multicolumn{8}{|l|}{ Controls: } \\
\hline $\ln ($ nemp) & $\begin{array}{l}0.2902^{\star \star \star \star} \\
(0.0421)\end{array}$ & $\begin{array}{l}0.2832^{\star \star \star} \\
(0.0408)\end{array}$ & $\begin{array}{l}0.2880^{\star \star \star} \\
(0.0408)\end{array}$ & $\begin{array}{l}0.2698^{\star \star \star} \\
(0.0426)\end{array}$ & $\begin{array}{l}0.2483^{\star \star \star} \\
(0.0389)\end{array}$ & $\begin{array}{l}0.2740^{\star \star \star} \\
(0.0449)\end{array}$ & $\begin{array}{l}0.2209^{\star \star \star} \\
(0.0398)\end{array}$ \\
\hline 1yrret & $\begin{array}{c}0.0575 \\
(0.1708)\end{array}$ & $\begin{array}{c}0.0420 \\
(0.1641)\end{array}$ & $\begin{array}{c}0.0506 \\
(0.1642)\end{array}$ & $\begin{array}{l}-0.0108 \\
(0.1596)\end{array}$ & $\begin{array}{l}-0.0023 \\
(0.1625)\end{array}$ & $\begin{array}{c}0.0273 \\
(0.1759)\end{array}$ & $\begin{array}{l}-0.0353 \\
(0.1565)\end{array}$ \\
\hline 2 yrret & $\begin{array}{c}0.0553 \\
(0.0762)\end{array}$ & $\begin{array}{c}0.0322 \\
(0.0775)\end{array}$ & $\begin{array}{c}0.0320 \\
(0.0760)\end{array}$ & $\begin{array}{c}0.0203 \\
(0.0737)\end{array}$ & $\begin{array}{c}0.0245 \\
(0.0711)\end{array}$ & $\begin{array}{c}0.0478 \\
(0.0799)\end{array}$ & $\begin{array}{c}0.0171 \\
(0.0731)\end{array}$ \\
\hline idiorisk & $\begin{array}{l}-5.7980 \\
(4.6049)\end{array}$ & $\begin{array}{l}-5.5133 \\
(4.7103)\end{array}$ & $\begin{array}{l}-5.9724 \\
(4.2798)\end{array}$ & $\begin{array}{l}-3.3600 \\
(4.4504)\end{array}$ & $\begin{array}{l}-3.8851 \\
(4.2208)\end{array}$ & $\begin{array}{l}-4.4411 \\
(5.0074)\end{array}$ & $\begin{array}{l}-2.4559 \\
(4.8669)\end{array}$ \\
\hline tdebt & $\begin{array}{l}-0.5433 \\
(0.3734)\end{array}$ & $\begin{array}{l}-0.3520 \\
(0.3718)\end{array}$ & $\begin{array}{l}-0.3594 \\
(0.3946)\end{array}$ & $\begin{array}{c}-0.7146^{\star} \\
(0.3659)\end{array}$ & $\begin{array}{l}-0.7615^{\star \star} \\
(0.3553)\end{array}$ & $\begin{array}{l}-0.4062 \\
(0.3883)\end{array}$ & $\begin{array}{l}-0.6092 \\
(0.4056)\end{array}$ \\
\hline tenure & $\begin{array}{c}0.0199 \\
(0.0154)\end{array}$ & $\begin{array}{c}0.0225 \\
(0.0159)\end{array}$ & $\begin{array}{c}0.0227 \\
(0.0157)\end{array}$ & $\begin{array}{c}0.0148 \\
(0.0158)\end{array}$ & $\begin{array}{c}0.0134 \\
(0.0151)\end{array}$ & $\begin{array}{c}0.0177 \\
(0.0151)\end{array}$ & $\begin{array}{c}0.0103 \\
(0.0148)\end{array}$ \\
\hline $\begin{array}{l}\text { tenure } \\
\times 10^{-2}\end{array}$ & $\begin{array}{c}0.0033 \\
(0.0003)\end{array}$ & $\begin{array}{l}-0.0021 \\
(0.0003)\end{array}$ & $\begin{array}{l}-0.0019 \\
(0.0003)\end{array}$ & $\begin{array}{c}0.0157 \\
(0.0003)\end{array}$ & $\begin{array}{c}0.0146 \\
(0.0003)\end{array}$ & $\begin{array}{c}0.0064 \\
(0.0003)\end{array}$ & $\begin{array}{c}0.0177 \\
(0.0003)\end{array}$ \\
\hline Constant & $\begin{array}{l}-1.7871^{\star \star \star} \\
(0.4559)\end{array}$ & $\begin{array}{l}-3.9527^{\star \star \star} \\
(0.7799)\end{array}$ & $\begin{array}{l}-4.4705^{\star \star \star} \\
(0.9340)\end{array}$ & $\begin{array}{l}-2.8581^{\star \star \star \star} \\
(0.6472)\end{array}$ & $\begin{array}{l}-3.9053^{\star \star \star} \\
(1.1527)\end{array}$ & $\begin{array}{l}-8.0034^{\star \star \star} \\
(2.4840)\end{array}$ & $\begin{array}{c}-11.5177^{\star \star \star} \\
(2.5826)\end{array}$ \\
\hline $\mathrm{N}$ & 252 & 252 & 252 & 252 & 252 & 252 & 252 \\
\hline Year FE & Yes & Yes & Yes & Yes & Yes & Yes & Yes \\
\hline Adj. $\mathrm{R}^{2}$ & 0.3147 & 0.3353 & 0.3360 & 0.3367 & 0.3437 & 0.3283 & 0.3683 \\
\hline
\end{tabular}

Note. Standard errors in parentheses. $* * * \mathrm{p}<0.01, * * \mathrm{p}<0.05, * \mathrm{p}<0.1$. Controls include the natural logarithm of number of employees [ $\ln (\mathrm{nemp})]$, one-year stock returns [1yrret], two-year stock returns [2yrret], idiosyncratic risk [idiorisk], total debt-to-total assets [tdebt], and CEO tenure [tenure] and its squared term [tenure ${ }^{2}$ ].

Some may argue that the efficiency improvements either precedes or is contemporaneous with increases in CEO pay, not instantaneous. To check this, we estimated the models presented in Tables 4-7 replacing the efficiency scores with their lag values and find very similar results (see Appendix B). Our results are also robust to alternate specifications of leverage - long-term debt ratio (not reported).

Lastly, certain CEO characteristics (other than tenure) may also play a role in the design of compensation contracts, the chief of them being the CEO gender. The gender of the CEO may play a crucial role in our study. In our sample, 8 out of 51 CEOs (15.7\%) were women, half of them were amongst the top five earners in the year 2015. In contrast, the proportion of female CEOs in the S\&P 1500 firms has been lingering around 3\% since the early 1990's, never going up higher than 5\% (Paul \& Sahni, 2010). Other Scholars (e.g. Smith, Smith, \& Verner, 2011; Borrenbergs, Vieira, \& Georgakopoulos, 2017) have reported similar proportions of female CEOs in other countries. We, therefore, re-run our pay models after including a dummy that represents female CEOs and find almost identical results (not reported).

\section{Conclusions}

The objective of this study was to investigate the casual relationship between static and dynamic financial efficiency of US apparel firms and CEO compensation. Our results indicate that there is a strong positive relationship between how efficient the firm is run and CEO compensation levels. Specifically, we find annual financial efficiency (CRS and VRS) and the total factor productivity changes are positive and significant to current year CEO compensation. Furthermore, we find that different aspects of efficiency have different impacts 
on CEO compensation - the largest pay impact arising from changes in scale efficiency. Our pay results are robust to alternate definitions of firm size and leverage, contemporaneous efficiency effects, and the inclusion of CEO gender as a control variable. Our results are largely consistent with the efficient contracting explanation and the pay-for-efficiency paradigm. We also identify our limitations: (i) our sample belongs to one industry apparel; and (ii) we do not address the differential impact of firm financial efficiency on different pay components - cash (salary and bonus), incentive packages (short-term and long-term), and other stock-based compensation. More interesting would be the impact of efficiency on the CEO's consumption of perquisites. Future research may address these limitations.

\section{Acknowledgements}

This paper is supported by the Business Research Center at the School of Business, Baldwin Wallace University.

\section{References}

Abed, S., Suwaidan, M., \& Slimani, S. (2014). The Determinants of Chief Executive Officer Compensation in Jordanian Industrial Corporations. International Journal of Economics and Finance, 6(12), 1-9. https://doi.org/10.5539/ijef.v6n12p110

Baiman, S. (1990). Agency research in managerial accounting: A second look. Accounting, Organizations and Society, 15(4), 314-371. https://doi.org/10.1016/0361-3682(90)90023-N

Banker, R. D., Darrough, M. N., Huang, R., \& Plehn-Dujowich, J. M. (2013). The Relation between CEO Compensation and Past Performance. The Accounting Review, 88(1), 1-30. https://doi.org/10.2308/accr-50274

Berrone, P., \& Gomez-Mejia, L. R. (2009). Environmental Performance and Executive Compensation: An Integrated Agency-Institutional Perspective. The Academy of Management Journal, 52(1), 103-126. https://doi.org/10.5465/AMJ.2009.36461950

Bloom, M., \& Milkovich, G. T. (1998). Relationships among Risk, Incentive Pay, and Organizational Performance. The Academy of Management Journal, 41(3), 283-297. https://doi.org/10.2307/256908

Borrenbergs, J., Vieira, R., \& Georgakopoulos, G. (2017). Remuneration Committees' Gender Composition as a Determinant of Executive Board Compensation Structure. International Business Research, 10(2), 135-146. https://doi.org/10.5539/ibr.v10n2p135

Boschen, J. F., \& Smith, K. J. (1995). You Can Pay Me Now and You Can Pay Me Later: The Dynamic Response of Executive Compensation to Firm Performance. The Journal of Business, 68(4), 577-608. https://doi.org/10.1086/296677

Bryan, S. H., Hwang, L., Klein, A., \& Lilien, S. B. (2000). Compensation of Outside Directors: An Empirical Analysis of Economic Determinants. (Working Paper). Retrieved June 1, 2017, from https://doi.org/10.2139/ssrn.244540

Carr, L. L. (1997). Strategic determinants of executive compensation in small publicly traded firms. Journal of Small Business Management, 35, 1-12.

Caves, D. W., Christensen, L. R., \& Diewert, E. W. (1982). The Economic Theory of Index Numbers and the Measurement of Input, Output, and Productivity. Econometrica, 50(6), 1393-1414. https://doi.org/10.2307/1913388

Chandra, P., Cooper, W. W., Li, S., \& Rahman, A. (1998). Using DEA To evaluate 29 Canadian textile companies - Considering returns to scale. International Journal of Production Economics, 54(2), 129-141. https://doi.org/10.1016/S0925-5273(97)00135-7

Cooper, M. J., Gulen, H., \& Rau, R. P. (2016). Performance for Pay? The Relation Between CEO Incentive Compensation and Future Stock Price Performance. (Working Paper). Retrieved November 11, 2017, from https://doi.org/10.2139/ssrn.1572085

Core, J. E., Holthausen, R. W., \& Larcker, D. F. (1999). Corporate governance, chief executive officer compensation, and firm performance. The Journal of Financial Economics, 51, 371-406. https://doi.org/10.1016/S0304-405X(98)00058-0

Deliktas, E. (2002). An analysis of efficiency and total factor productivity growth of private manufacturing industry in Turkey. Metu Studies in Development, 29(3-4), 247-284

Eisenhardt, K. M. (1989). Agency Theory: An Assessment and Review. The Academy of Management Review, 
14(1), 57-74. https://doi.org/10.5465/AMR.1989.4279003

Engel, E., Hayes, R. M., \& Wang, X. (2003). CEO turnover and properties of accounting information. Journal of Accounting and Economics, 36, 197-226. https://doi.org/10.1016/j.jacceco.2003.08.001

Equilar (2016). 2016 CEO Pay Trends. Redwood City, CA: Equilar.

Eslami-Bidgoli, G., \& Kashani-Poor, M. (2004). A comparison between methods of evaluating bank branches' performance and offering a suitable method. Journal of Accounting and Auditing, 38, 12-20.

Fama, E. F. (1980). Agency Problems and the Theory of the Firm. The Journal of Political Economy, 88(2), 288-307. https://doi.org/10.1086/260866

Fare, R., Grosskopf, S., \& Norris, M. (1997). Productivity Growth, Technical Progress, and Efficiency Change in Industrialized Countries: Reply. The American Economic Review, 87(5), 1040-1044.

Feroz, E. H., Kim, S., \& Raab, R. L. (2003). Financial Statement Analysis: A Data Envelopment Analysis Approach. Journal of the Operational Research Society, 54, 48-58. https://doi.org/10.1057/palgrave.jors.2601475

Finkelstein, S., \& Hambrick, D. C. (1989). Chief Executive Compensation: A Study of the Intersection of Markets and Political Processes. Strategic Management Journal, 10(2), 121-134. https://doi.org/10.1002/smj.4250100203

Francis, T. (2016, July 25). Best-Paid CEOs run some of the worst-performing companies: Analysis by MSCI calls into question the idea that high CEO pay helps drive better results. The Wall Street Journal. Retrieved from https://www.wsj.com/articles/best-paid-ceos-run-some-of-worst-performing-companies-1469419262

Gerhart, B., \& Milkovich, G. T. (1992). Employee compensation: Research and practice. In M. D. Dunnette \& L. M. Hough (Eds.), Handbook of industrial and organizational psychology (Vol. 3, pp. 481-569). Palo Alto, CA: Consulting Psychologists Press.

Gibbons, R., \& Murphy, K. J. (1992). Optimal Incentive Contracts in the Presence of Career Concerns: Theory and Evidence. Journal of Political Economy, 100(3), 468-505.

Gormley, T. A., Matsa, D. A., \& Milbourn, T. (2013). CEO compensation and corporate risk: Evidence from a natural experiment. Journal of Accounting and Economics, 56(2-3), 79-101. https://doi.org/10.1016/j.jacceco.2013.08.001

Grifell-Tatje, E., \& Lovell, C. A. K. (1995). A note on the Malmquist productivity index. Economics Letters, 47(2), 169-175. https://doi.org/10.1016/0165-1765(94)00497-P

Halkos, G. E., \& Salamouris, D. S. (2004). Efficiency measurement of the Greek commercial banks with the use of financial ratios: a data envelopment analysis approach. Management Accounting Research, 15(2), 201-224. https://doi.org/10.1016/j.mar.2004.02.001

Hermalin, B. E., \& Weisbach, M. S. (1998). Endogenously Chosen Boards of Directors and Their Monitoring of the CEO. The American Economic Review, 88, 96-118.

Hill, C., \& Phan, P. (1991). CEO Tenure as a Determinant of CEO Pay. The Academy of Management Journal, 34(3), 707-717.

Ismail, S. B., Yabai, N. V., \& Hahn, L. J. (2014). Relationship between CEO Pay and Firm Performance: Evidences from Malaysia Listed Firms. IOSR Journal of Economics and Finance, 3(6), 14-31. https://doi.org/10.9790/5933-0361431

Jarzebowski, S. (2013). Parametric and Nonparametric Efficiency Measurement: Comparison of Results. Quantitative Methods in Economics, 14(1), 170-179.

Jensen, M. C. (1986). Agency Costs of Free Cash Flow, Corporate Finance, and Takeovers. The American Economic Review, 76, 323-29.

Jensen, M. C., \& Murphy, K. J. (1990). Performance Pay and Top-Management Incentives. Journal of Political Economy, 98(2), 225-264.

Jensen, M. C., \& Murphy, K. J. (2010). CEO Incentives - It's Not How Much You Pay, But How. Journal of Applied Corporate Finance, 22(1), 64-76. https://doi.org/10.1111/j.1745-6622.2010.00262.x

Jouber, H., \& Fakhfakh, H. (2011). Does CEOs Performance-based Compensation Waits on Shareholders? A Cross National Analysis. International Journal of Business Administration, 2(3), 68-82. 
https://doi.org/10.5430/ijba.v2n3p68

Lee, K., Leem, B., Lee, C. W., \& Lee, C. (2011). Malmquist Productivity Index using DEA frontier in Stata. Stata Journal, 2(2), 1-9.

Leone, A. J., Wu, J. S., \& Zimmerman, J. L. (2006). Asymmetric sensitivity of CEO cash compensation to stock returns. Journal of Accounting and Economics, 42, 167-192. https://doi.org/10.1016/j.jacceco.2006.04.001

Lewellen, W. G., \& Huntsman, B. (1970). Managerial Pay and Corporate Performance. The American Economic Review, 60, 710-720.

Mahadevan, R. (2002). A DEA Approach to Understanding the Productivity Growth of Malaysia's Manufacturing Industries. Asia Pacific Journal of Management, 19(4), 587-600. https://doi.org/10.1023/A:1020577811369

Mishel, L., \& Davis, A. (2015). Top CEOs make 300 times more than typical workers: Pay growth surpasses stock gains and wage growth of the top 0.1 percent. (Economic Policy Institute Issue Brief 339). Retrieved January 27, 2018, from https://www.epi.org/files/2015/top-ceos-make-300-times-more-than-typical-workers.pdf

Mishel, L., \& Schieder, J. (2017). CEO pay remains high relative to the pay of typical workers and high-wage earners. (Economic Policy Institute Report). Retrieved January 27, 2018, from: https://www.epi.org/files/pdf/130354.pdf

Pathak, S., Hoskisson, R. E., \& Johnson, R. A. (2014). Settling up in CEO compensation: The impact of divestiture intensity and contextual factors in refocusing firms. Strategic Management Journal, 35, 1124-1143. https://doi.org/10.1002/smj.2153

Paul, S. L., \& Sahni, H. (2010). Women in Top Management and Job Self Selection. (Working Paper). Retrieved October 21, 2017, from https://doi.org/10.2139/ssrn.2870673

Paul, S. L., \& Sahni, H. (2017). CEO Networks and Shareholder Value. (Working Paper). Retrieved March 16, 2018, from https://ssrn.com/abstract=3117679

Shaw, K. W., \& Zhang, M. H. (2010). Is CEO Cash Compensation Punished for Poor Firm Performance? The Accounting Review, 85(3), 1065-1095. https://doi.org/10.2308/accr.2010.85.3.1065

Sigler, K. J. (2011). CEO Compensation and Company Performance. Business and Economics Journal, 11, 1-8.

Smith, N., Smith, V., \& Verner, M. (2011). Why are so few females promoted into CEO and vice-president positions? Danish empirical evidence 1997-2007. Industrial and Labor Relations Review, 66(2), 380-408.

Tehrani, R., Mehragan, M. R., \& Golkani, M. R. (2012). A Model for Evaluating Financial Performance of Companies by Data Envelopment Analysis - A Case Study of 36 Corporations Affiliated with a Private Organization. International Business Research, 5(8), 8-16. http://dx.doi.org/10.5539/ibr.v5n8p8

Tosi, H. L., Werner, S., Katz, J. P., \& Gomez-Mejia, L. R. (2000). How Much Does Performance Matter? A Meta-Analysis of CEO Pay Studies. Journal of Management, 26(2), 301-339. https://doi.org/10.1177/014920630002600207

Vemala, P., Nguyen, L., Nguyen, D., \& Kommasani, A. (2014). CEO Compensation: Does Financial Crisis Matter? International Business Research, 7(4), 125-134. https://doi.org/10.5539/ibr.v7n4p125

Weichenrieder, A. J. (2009). Profit shifting in the EU: evidence from Germany. International Tax and Public Finance, 16(3), 281-297. https://doi.org/10.1007/s10797-008-9068-x

Williamson, O. E. (1988). Corporate Finance and Corporate Governance. Journal of Finance, 43, 567-92. https://doi.org/10.2307/2328184

Yatim, P. (2012). Boardroom Pay, Performance and Corporate Governance in Malaysia. The Business and Management Review, 2(2), 37-51.

\section{Notes}

Note 1. CRS assumes output changes are in proportion to input changes (e.g. doubling inputs leads to doubling output). On the other hand, VRS assumes that the production technology may exhibit increasing or decreasing returns to scale.

Note 2. The inclusion of leverage ratios in the first stage (efficiency estimation stage) made our models unstable. Thus, we accounted for leverage in the second stage (CEO pay model). 


\section{Appendix A}

\section{Sample of firms included in this study.}

\section{Table A1. Company List}

\begin{tabular}{llll}
\hline Ticker & Company name & Exchange & Headquarters \\
\hline AEO & American Eagle Outfitters Inc & NYSE & Pittsburgh, PA \\
ANF & Abercrombie \& Fitch Co & NYSE & New Albany, OH \\
ANN & ANN Inc & NYSE & New York City, NY \\
AROPQ & ARO Liquidation Inc & NYSE & New York City, NY \\
BEBE & Bebe stores inc & NASDAQ & Brisbane, CA \\
BKE & Buckle Inc & NYSE & Kearney, NE \\
CAL & Caleres Inc & NYSE & Clayton, MO \\
CATO & Cato Corp & NYSE & Charlotte, NC \\
CRI & Carter's Inc & NYSE & Atlanta, GA \\
DEST & Destination Maternity Corp & NASDAQ & Moorestown, NJ \\
DXLG & Destination XL Group Inc & NASDAQ & Canton, MA \\
FINL & Finish Line Inc & NASDAQ & Indianapolis, IN \\
FL & Foot Locker Inc & NYSE & New York City, NY \\
GCO & Genesco Inc & NYSE & Nashville, TN \\
GPS & Gap Inc & NYSE & San Francisco, CA \\
LB & L Brands Inc & NASDAQ & Secaucus, NJ \\
PLCE & Childrens Place Inc & NASDAQ & Anaheim, CA \\
PSUNQ & Pacific Sunwear of California Inc & NASDAQ & Dublin, CA \\
ROST & Ross Stores Inc & NASDAQ & Jacksonville, FL \\
SMRT & Stein Mart Inc & NYSE & Framingham, MA \\
TJX & TJX Cos Inc &
\end{tabular}




\section{Appendix B}

\section{Robustness Checks: The relationship between CEO Pay and Lag Efficiency Scores.}

Table B1. Total Compensation and Lag Efficiency

\begin{tabular}{|c|c|c|c|c|c|c|c|}
\hline \multirow{3}{*}{$\begin{array}{l}\text { Efficiency: } \\
\text { Lag CRS }\end{array}$} & Model 1 & Model 2 & Model 3 & Model 4 & Model 5 & Model 6 & Model 7 \\
\hline & & & & & & & \\
\hline & & $\begin{array}{l}1.4785^{\star \star} \\
(0.6881)\end{array}$ & & & & & \\
\hline Lag VRS & & & $\begin{array}{l}1.9522^{\star \star} \\
(0.8139)\end{array}$ & & & & \\
\hline Lag TFPCH & & & & $\begin{array}{l}1.1313^{\star \star} \\
(0.5375)\end{array}$ & & & \\
\hline Lag EFFCH & & & & & $\begin{array}{c}0.3068 \\
(0.5694)\end{array}$ & & \\
\hline Lag TECHCH & & & & & $\begin{array}{l}1.9673^{\star \star} \\
(0.8631)\end{array}$ & & $\begin{array}{l}2.1296^{\star \star} \\
(0.8544)\end{array}$ \\
\hline Lag PECH & & & & & & $\begin{array}{c}-0.2954 \\
(0.6780)\end{array}$ & $\begin{array}{c}-0.1128 \\
(0.6780)\end{array}$ \\
\hline Lag SECH & & & & & & $\begin{array}{c}3.5954 \\
(2.6373)\end{array}$ & $\begin{array}{c}4.9639^{\star} \\
(2.5442)\end{array}$ \\
\hline Controls: & & & & & & & \\
\hline $\ln ($ at $)$ & $\begin{array}{l}0.5672^{\star \star \star} \\
(0.0462)\end{array}$ & $\begin{array}{l}0.5671^{\star \star \star} \\
(0.0505)\end{array}$ & $\begin{array}{l}0.5702^{\star \star \star} \\
(0.0502)\end{array}$ & $\begin{array}{l}0.5551^{\star \star \star} \\
(0.0469)\end{array}$ & $\begin{array}{l}0.5320^{\star \star \star} \\
(0.0478)\end{array}$ & $\begin{array}{l}0.5637^{\star \star \star} \\
(0.0507)\end{array}$ & $\begin{array}{l}0.5065^{\star \star \star} \\
(0.0467)\end{array}$ \\
\hline 1yrret & $\begin{array}{l}-0.0207 \\
(0.1425)\end{array}$ & $\begin{array}{l}-0.0618 \\
(0.1524)\end{array}$ & $\begin{array}{l}-0.0643 \\
(0.1341)\end{array}$ & $\begin{array}{l}-0.1137 \\
(0.1344)\end{array}$ & $\begin{array}{l}-0.1143 \\
(0.1405)\end{array}$ & $\begin{array}{l}-0.0575 \\
(0.1709)\end{array}$ & $\begin{array}{l}-0.1019 \\
(0.1647)\end{array}$ \\
\hline 2 yrret & $\begin{array}{c}0.1084^{\star} \\
(0.0654)\end{array}$ & $\begin{array}{c}0.0927 \\
(0.0691)\end{array}$ & $\begin{array}{c}0.0935 \\
(0.0745)\end{array}$ & $\begin{array}{c}0.0718 \\
(0.0696)\end{array}$ & $\begin{array}{c}0.0744 \\
(0.0658)\end{array}$ & $\begin{array}{c}0.0977 \\
(0.0815)\end{array}$ & $\begin{array}{c}0.0658 \\
(0.0671)\end{array}$ \\
\hline idiorisk & $\begin{array}{c}0.9323 \\
(3.3678)\end{array}$ & $\begin{array}{c}1.4491 \\
(3.5361)\end{array}$ & $\begin{array}{c}1.2199 \\
(3.6154)\end{array}$ & $\begin{array}{c}3.5337 \\
(3.6868)\end{array}$ & $\begin{array}{c}3.3701 \\
(3.8775)\end{array}$ & $\begin{array}{c}1.8757 \\
(3.6816)\end{array}$ & $\begin{array}{c}3.7359 \\
(3.9389)\end{array}$ \\
\hline tdebt & $\begin{array}{l}-0.0709 \\
(0.3117)\end{array}$ & $\begin{array}{c}0.1470 \\
(0.3364)\end{array}$ & $\begin{array}{c}0.1502 \\
(0.3220)\end{array}$ & $\begin{array}{l}-0.0907 \\
(0.3187)\end{array}$ & $\begin{array}{l}-0.2065 \\
(0.3227)\end{array}$ & $\begin{array}{c}0.1028 \\
(0.3301)\end{array}$ & $\begin{array}{l}-0.1015 \\
(0.3352)\end{array}$ \\
\hline tenure & $\begin{array}{l}0.0308^{\star \star} \\
(0.0138)\end{array}$ & $\begin{array}{l}0.0384^{\star \star \star} \\
(0.0144)\end{array}$ & $\begin{array}{l}0.0388^{\star \star \star \star} \\
(0.0142)\end{array}$ & $\begin{array}{l}0.0329^{\star \star} \\
(0.0146)\end{array}$ & $\begin{array}{l}0.0309^{\star \star} \\
(0.0143)\end{array}$ & $\begin{array}{l}0.0353^{\star \star} \\
(0.0146)\end{array}$ & $\begin{array}{l}0.0292^{\star \star} \\
(0.0140)\end{array}$ \\
\hline tenure $^{2}$ & $\begin{array}{l}-0.0006^{\star \star} \\
(0.0003)\end{array}$ & $\begin{array}{l}-0.0008^{\star \star} \\
(0.0003)\end{array}$ & $\begin{array}{l}-0.0008^{\star \star \star} \\
(0.0003)\end{array}$ & $\begin{array}{l}-0.0006^{\star \star} \\
(0.0003)\end{array}$ & $\begin{array}{l}-0.0006^{\star \star} \\
(0.0003)\end{array}$ & $\begin{array}{l}-0.0007^{\star \star} \\
(0.0003)\end{array}$ & $\begin{array}{l}-0.0006^{\star \star} \\
(0.0003)\end{array}$ \\
\hline Constant & $\begin{array}{l}-3.4355^{\star \star \star} \\
(0.4160)\end{array}$ & $\begin{array}{l}-4.5934^{\star \star \star \star} \\
(0.7220)\end{array}$ & $\begin{array}{l}-5.0695^{\star \star \star} \\
(0.8049)\end{array}$ & $\begin{array}{l}-4.1578^{\star \star \star \star} \\
(0.6852)\end{array}$ & $\begin{array}{l}-5.0732^{\star \star \star} \\
(1.2015)\end{array}$ & $\begin{array}{l}-6.4816^{\star \star} \\
(2.5322)\end{array}$ & $\begin{array}{l}-9.6399^{\star \star \star} \\
(2.7169)\end{array}$ \\
\hline $\mathrm{N}$ & 252 & 231 & 231 & 231 & 231 & 231 & 231 \\
\hline Year FE & Yes & Yes & Yes & Yes & Yes & Yes & Yes \\
\hline Adj. $R^{2}$ & 0.4892 & 0.4686 & 0.4711 & 0.4750 & 0.4838 & 0.4622 & 0.4918 \\
\hline
\end{tabular}

Note. Standard errors in parentheses. $* * * \mathrm{p}<0.01, * * \mathrm{p}<0.05, * \mathrm{p}<0.1$. Controls include the natural logarithm of total assets [ $\ln (a t)]$, one-year stock returns [1yrret], two-year stock returns [2yrret], idiosyncratic risk [idiorisk], total debt-to-total assets [tdebt], and CEO tenure [tenure] and its squared term [tenure ${ }^{2}$ ]. 
Table B2. Total Compensation, Lag Efficiency and Leverage

\begin{tabular}{|c|c|c|c|c|c|c|c|}
\hline \multirow{3}{*}{$\begin{array}{l}\text { Efficiency: } \\
\text { Lag CRS }\end{array}$} & Model 1 & Model 2 & Model 3 & Model 4 & Model 5 & Model 6 & Model 7 \\
\hline & & & & & & & \\
\hline & & $\begin{array}{l}2.1397^{\star \star \star} \\
(0.7755)\end{array}$ & & & & & \\
\hline Lag VRS & & & $\begin{array}{l}2.6644^{\star \star \star} \\
(0.9453)\end{array}$ & & & & \\
\hline Lag TFPCH & & & & $\begin{array}{l}1.5767^{\star \star \star} \\
(0.5768)\end{array}$ & & & \\
\hline Lag EFFCH & & & & & $\begin{array}{c}0.5044 \\
(0.7175)\end{array}$ & & \\
\hline Lag TECHCH & & & & & $\begin{array}{l}2.6515^{\star \star \star} \\
(0.8653)\end{array}$ & & $\begin{array}{l}2.8833^{\star \star \star} \\
(0.8645)\end{array}$ \\
\hline Lag PECH & & & & & & $\begin{array}{c}-0.3599 \\
(0.8573)\end{array}$ & $\begin{array}{c}-0.1518 \\
(0.7786)\end{array}$ \\
\hline Lag SECH & & & & & & $\begin{array}{c}5.5803^{\star} \\
(3.0282)\end{array}$ & $\begin{array}{l}7.3597^{\star \star \star \star} \\
(2.7556)\end{array}$ \\
\hline Controls: & & & & & & & \\
\hline $\ln ($ nemp) & $\begin{array}{l}0.2902^{\star \star \star} \\
(0.0420)\end{array}$ & $\begin{array}{l}0.2969^{\star \star \star} \\
(0.0444)\end{array}$ & $\begin{array}{l}0.3025^{\star \star \star} \\
(0.0460)\end{array}$ & $\begin{array}{l}0.2836^{\star \star \star} \\
(0.0427)\end{array}$ & $\begin{array}{l}0.2568^{\star \star \star} \\
(0.0415)\end{array}$ & $\begin{array}{l}0.2869^{\star \star \star} \\
(0.0471)\end{array}$ & $\begin{array}{l}0.2275^{\star \star \star} \\
(0.0421)\end{array}$ \\
\hline 1yrret & $\begin{array}{c}0.0575 \\
(0.1668)\end{array}$ & $\begin{array}{c}0.0135 \\
(0.1749)\end{array}$ & $\begin{array}{c}0.0086 \\
(0.1810)\end{array}$ & $\begin{array}{l}-0.0582 \\
(0.1622)\end{array}$ & $\begin{array}{l}-0.0558 \\
(0.1542)\end{array}$ & $\begin{array}{c}0.0224 \\
(0.2030)\end{array}$ & $\begin{array}{l}-0.0357 \\
(0.1994)\end{array}$ \\
\hline 2 yrret & $\begin{array}{c}0.0553 \\
(0.0850)\end{array}$ & $\begin{array}{c}0.0345 \\
(0.0891)\end{array}$ & $\begin{array}{c}0.0363 \\
(0.0865)\end{array}$ & $\begin{array}{c}0.0067 \\
(0.0809)\end{array}$ & $\begin{array}{c}0.0115 \\
(0.0806)\end{array}$ & $\begin{array}{c}0.0394 \\
(0.0899)\end{array}$ & $\begin{array}{c}0.0018 \\
(0.0832)\end{array}$ \\
\hline idiorisk & $\begin{array}{l}-5.7980 \\
(4.4445)\end{array}$ & $\begin{array}{l}-4.9994 \\
(4.4611)\end{array}$ & $\begin{array}{l}-5.2661 \\
(4.8203)\end{array}$ & $\begin{array}{l}-2.0557 \\
(4.6183)\end{array}$ & $\begin{array}{l}-2.2892 \\
(4.5778)\end{array}$ & $\begin{array}{l}-4.4285 \\
(5.0549)\end{array}$ & $\begin{array}{l}-1.6594 \\
(4.7754)\end{array}$ \\
\hline tdebt & $\begin{array}{c}-0.5433 \\
(0.3866)\end{array}$ & $\begin{array}{l}-0.2700 \\
(0.3920)\end{array}$ & $\begin{array}{l}-0.2889 \\
(0.4076)\end{array}$ & $\begin{array}{l}-0.5822 \\
(0.4006)\end{array}$ & $\begin{array}{c}-0.6770^{\star} \\
(0.3894)\end{array}$ & $\begin{array}{c}-0.3009 \\
(0.4194)\end{array}$ & $\begin{array}{l}-0.4647 \\
(0.4174)\end{array}$ \\
\hline tenure & $\begin{array}{c}0.0199 \\
(0.0156)\end{array}$ & $\begin{array}{c}0.0289^{\star} \\
(0.0169)\end{array}$ & $\begin{array}{c}0.0293^{\star} \\
(0.0172)\end{array}$ & $\begin{array}{c}0.0212 \\
(0.0163)\end{array}$ & $\begin{array}{c}0.0187 \\
(0.0160)\end{array}$ & $\begin{array}{c}0.0240 \\
(0.0165)\end{array}$ & $\begin{array}{c}0.0165 \\
(0.0153)\end{array}$ \\
\hline $\begin{array}{l}\text { tenure }{ }^{2} \\
\times 10^{-2}\end{array}$ & $\begin{array}{c}0.0033 \\
(0.0003)\end{array}$ & $\begin{array}{l}-0.0153 \\
(0.0003)\end{array}$ & $\begin{array}{l}-0.0149 \\
(0.0003)\end{array}$ & $\begin{array}{c}0.0031 \\
(0.0003)\end{array}$ & $\begin{array}{c}0.0035 \\
(0.0003)\end{array}$ & $\begin{array}{l}-0.0076 \\
(0.0003)\end{array}$ & $\begin{array}{c}0.0039 \\
(0.0003)\end{array}$ \\
\hline Constant & $\begin{array}{l}-1.7871^{\star \star \star} \\
(0.4466)\end{array}$ & $\begin{array}{l}-3.6518^{\star \star \star} \\
(0.7593)\end{array}$ & $\begin{array}{l}-4.2007^{\star \star \star \star} \\
(0.9387)\end{array}$ & $\begin{array}{l}-2.9760^{\star \star \star} \\
(0.7156)\end{array}$ & $\begin{array}{l}-4.2496^{\star \star \star} \\
(1.2671)\end{array}$ & $\begin{array}{l}-6.7829^{\star \star} \\
(2.8213)\end{array}$ & $\begin{array}{c}-11.0030^{\star \star \star \star ~} \\
(2.8758)\end{array}$ \\
\hline $\mathrm{N}$ & 252 & 231 & 231 & 231 & 231 & 231 & 231 \\
\hline Year FE & Yes & Yes & Yes & Yes & Yes & Yes & Yes \\
\hline Adj. $R^{2}$ & 0.3147 & 0.2946 & 0.2968 & 0.3057 & 0.3210 & 0.2846 & 0.3406 \\
\hline
\end{tabular}

Note. Standard errors in parentheses. $* * * \mathrm{p}<0.01, * * \mathrm{p}<0.05, * \mathrm{p}<0.1$. Controls include the natural logarithm of number of employees [ $\ln (\mathrm{nemp})]$, one-year stock returns [1yrret], two-year stock returns [2yrret], idiosyncratic risk [idiorisk], total debt-to-total assets [tdebt], and CEO tenure [tenure] and its squared term [tenure ${ }^{2}$ ].

\section{Copyrights}

Copyright for this article is retained by the author(s), with first publication rights granted to the journal.

This is an open-access article distributed under the terms and conditions of the Creative Commons Attribution license (http://creativecommons.org/licenses/by/4.0/). 